\title{
Reduced Spill at Hydropower Dams: Opportunities for More Generation and Increased Fish Protection
}

September 2006

Prepared by Charles C. Coutant Roger Mann Michael J. Sale

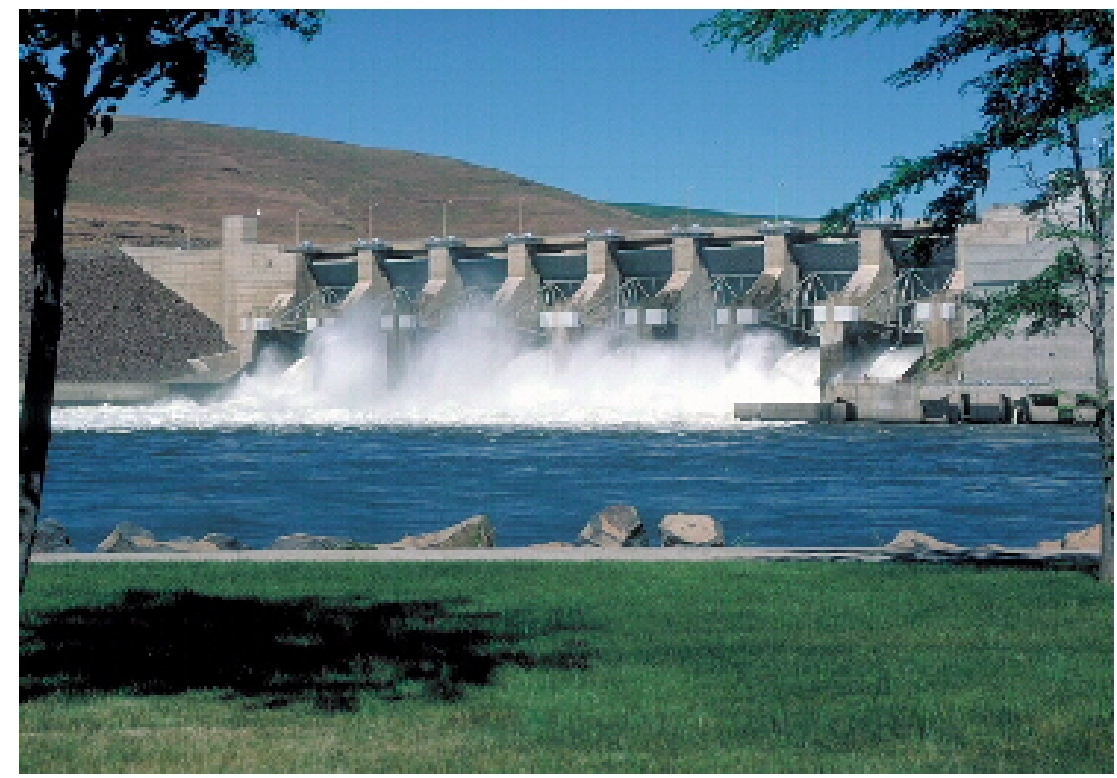

\section{U.S. Department of Energy Energy Efficiency and Renewable Energy Wind and Hydropower Technologies}




\title{
DOCUMENT AVAILABILITY
}

Reports produced after January 1, 1996, are generally available free via the U.S. Department of Energy (DOE) Information Bridge.

Web site http://www.osti.gov/bridge

Reports produced before January 1, 1996, may be purchased by members of the public from the following source.

\author{
National Technical Information Service \\ 5285 Port Royal Road \\ Springfield, VA 22161 \\ Telephone 703-605-6000 (1-800-553-6847) \\ TDD 703-487-4639 \\ Fax 703-605-6900 \\ E-mail info@ ntis.fedworld.gov \\ Web site http://www.ntis.gov/support/ordernowabout.htm
}

Reports are available to DOE employees, DOE contractors, Energy

Technology Data Exchange (ETDE) representatives, and International Nuclear Information System (INIS) representatives from the following source.

Office of Scientific and Technical Information

P.O. Box 62

Oak Ridge, TN 37831

Telephone 865-576-8401

Fax 865-576-5728

E-mail reports@adonis.osti.gov

Web site http://www.osti.gov/contact.html

This report was prepared as an account of work sponsored by an agency of the United States Government. Neither the United States Government nor any agency thereof, nor any of their employees, makes any warranty, express or implied, or assumes any legal liability or responsibility for the accuracy, completeness, or usefulness of any information, apparatus, product, or process disclosed, or represents that its use would not infringe privately owned rights. Reference herein to any specific commercial product, process, or service by trade name, trademark, manufacturer, or otherwise, does not necessarily constitute or imply its endorsement, recommendation, or favoring by the United States Government or any agency thereof. The views and opinions of authors expressed herein do not necessarily state or reflect those of the United States Government or any agency thereof. 
Environmental Sciences Division

\title{
REDUCED SPILL AT HYDROPOWER DAMS: OPPORTUNITIES FOR MORE GENERATION AND INCREASED FISH PROTECTION
}

\author{
Charles C. Coutant \\ Environmental Sciences Division \\ Oak Ridge National Laboratory \\ Oak Ridge, Tennessee 37831-6036 \\ Roger Mann \\ RMecon \\ 1677 Colusa Avenue \\ Davis, California 95616 \\ Michael J. Sale \\ Environmental Sciences Division \\ Oak Ridge National Laboratory \\ Oak Ridge, Tennessee 37831-6036
}

Date Published: September 2006

Prepared for

U. S. Department of Energy

Office of Energy Efficiency and Renewable Energy

Wind and Hydropower Technologies

Budget Activity EB 4400000

Prepared by

OAK RIDGE NATIONAL LABORATORY

Oak Ridge, Tennessee 37831 managed by

UT-BATTELLE, LLC

for the

U.S. DEPARTMENT OF ENERGY

under contract DE-AC05-00OR22725 



\section{CONTENTS}

Page

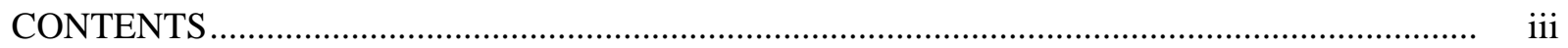

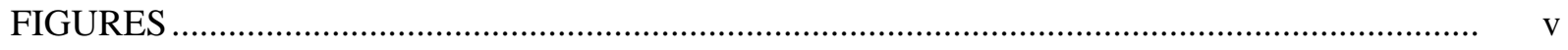

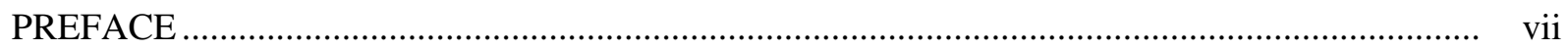

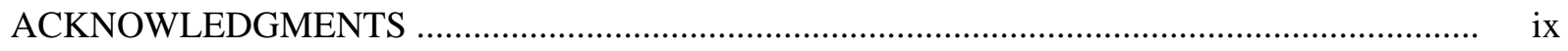

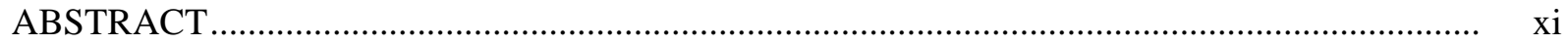

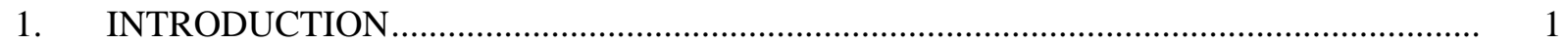

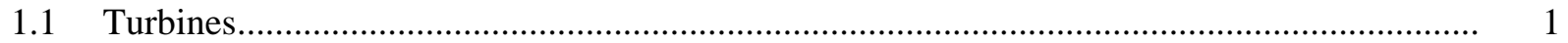

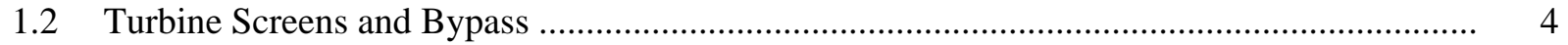

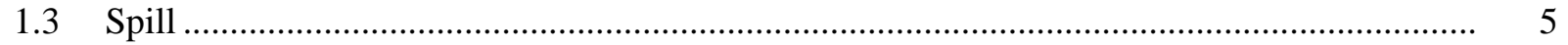

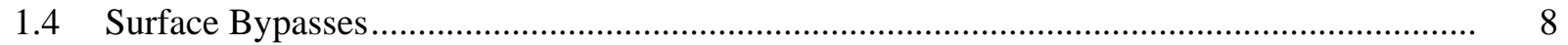

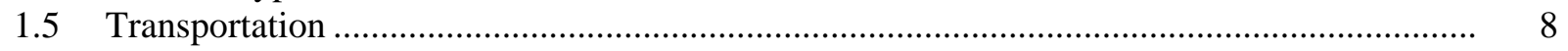

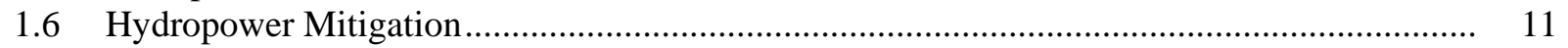

2. SOCIETAL COSTS OF SPILL FOR FISH PASSAGE …..................................................... 12

3. STRATEGIC ALTERNATIVES TO MANAGED SPILL …................................................... 14

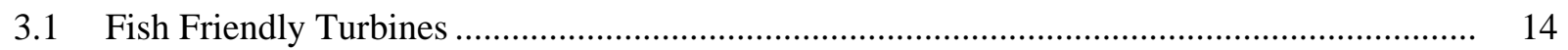

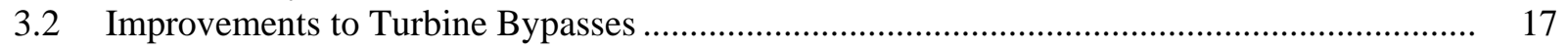

3.3 Ice and Trash Sluiceway at the Dalles Dam................................................................ 17

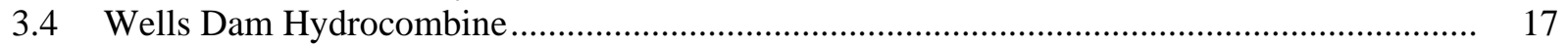

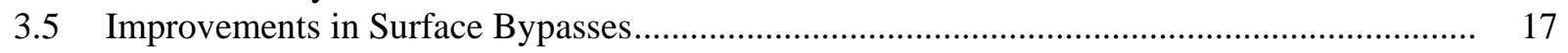

3.5.1 Surface Bypass at Rocky Reach Dam .................................................... 18

3.5.2 Surface Bypass at Corps Dams................................................................. 18

3.5.3 Wanapum Dam Surface Bypass Prototype................................................... 18

3.5.4 Bonneville Corner Collector..................................................................... 18

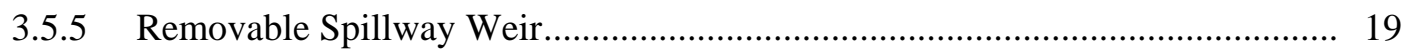

3.5.6 Summary of Alternatives.......................................................................... 19

4. THE 2004 FCRPS SPILL CONTROVERSY …................................................................. 20

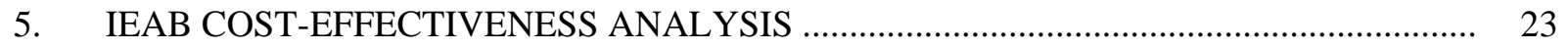

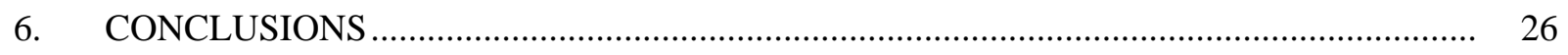

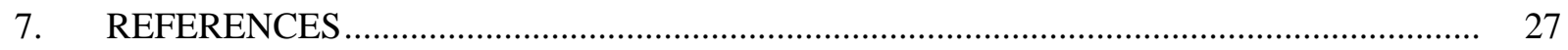





\section{FIGURES}

Figure 1. Major dams in the Columbia River Basin.

Figure 3. Photograph of The Dalles Dam, showing ice and trash sluiceway (small white plume next to the powerhouse) that has been effective as a surface bypass for juvenile salmon.

Figure 4. Transportation of juvenile salmon by barge around mainstem dams.

Figure 5. Cross section of a generalized hydropower dam in the Columbia River basin, showing a submerged screen to intercept fish heading toward the turbine and the bypass channel inside the dam that leads to the tailwater.

Figure 6. A generalized dam on the Columbia River, with two cross sections of the spillway showing typical spill at the base of a Tainter gate and surface spill.

Figure 7. Diagram of the Removable Spillway Weir developed by the U. S. Army Corps of Engineers.

Figure 8. Photos of the Removable Spillway Weir at Lower Granite Dam. Counter clockwise, from upper left: RSW on land; forebay view of RSW in place; RSW in place, view from the dam; RSW spilling water at the right-hand spill bay.

Figure 9. Bonneville Dam showing locations of the Corner Collector (1), original Corner Collector outfall (2), new Corner Collector outfall location (3) and the outfall location for the juvenile salmon turbine bypass.

Figure 10. Comparison of the design features of the existing (Unit 9) and new (Unit 8) runners at Wanapum Dam.

Figure 11. Advanced-design runner installed at Wanapum Dam Unit 8 in 2005 


\section{PREFACE}

There is intense debate in the U.S. Pacific Northwest about how to manage the Federal Columbia River Power System (FCRPS) and other hydropower dams in the Columbia River basin to accomplish the dual goals of providing inexpensive electricity to the region while recovering salmon populations. The Northwest Power and Conservation Act of 1980 (as amended in 1996) gave the region the mandate to do both in a balanced manner, and it formed the Northwest Power Planning Council (now called the Northwest Power and Conservation Council) to provide policy direction. The Council consists of two representatives from each of the four Northwest states (Washington, Oregon, Idaho, and Montana), and the Council employs a staff primarily in Portland, Oregon. The Council variously interacts with the so-called Action Agencies (U.S. Department of Energy's Bonneville Power Administration, U.S. Army Corps of Engineers, and U.S. Bureau of Reclamation) as well as NOAA Fisheries in implementing its Columbia River Basin Fish and Wildlife Program for mitigating fish and wildlife losses from constructing and operating the FCRPS and its analyses of power requirements for the region.

One of the more controversial management positions throughout the Council's tenure has been the use of river flow to assist downstream migrating juvenile salmon and steelhead. In particular, electricity generation is often foregone in order to spill water over spillways to move fish past dams without passing them through damaging turbines. During the generally spring migration period, much water is normally spilled because river flows exceed the hydraulic capacity of powerhouses to generate electricity. At other times, particularly late spring and early summer, spill is conducted at mainstem dams to benefit downstream fish passage, to the detriment of potential electricity generation (so-called managed or bypass spill). This occurs at both federal and non-federal dams; at non-federal dams, a spill requirement is part of the operating license by the Federal Energy Regulatory Commission.

The U.S. Department of Energy has espoused a goal of increasing hydropower generation at existing plants in the U.S by about $10 \%$. Because new sites for conventional hydropower are limited, the gains must come from innovative technologies (such as no-dam, inertial hydropower) or from efficiency improvements at present facilities. Reducing spill in order to reserve it for hydroelectricity generation is one important option for improving the amount of power obtained from existing facilities.

The argument has recently been made that selectively reducing managed spill for fish and generating electricity with the additional water could provide funds needed for research, development and deployment (RD\&D) of new technologies that could aid both fish passage and the economy in the long run. This arrangement, coupled with innovative financing of the RD\&D costs, could alleviate some of the problem of limited annual appropriations or other income for the action agencies in the Pacific Northwest. In a wider sense, generating (instead of spilling) will increase the supply and lower the cost of electricity in the U.S.

This report summarizes the spill issue in the Pacific Northwest. For perspective, background information is provided on the various fish-passage routes at a dam and research being conducted to improve their efficacy. The main message is that the region could use innovative economics as well as innovative fisheries research and engineering to accomplish its long-range goals to foster both salmon and electricity. 


\section{ACKNOWLEDGMENTS}

We thank the other members of the boards on which we serve, the Independent Scientific Advisory Board and the Independent Economic Analysis Board, respectively, of the Northwest Power and Conservation Council for our continuing education in matters related to salmon in the Northwest. G. F. Cada and B. T. Smith provided useful comments on our draft.

This report is a product of the U.S. Department of Energy's Office of Energy Efficiency and Renewable Energy, Office of Wind and Hydropower Technologies 


\begin{abstract}
This report indicates that reduction of managed spill at hydropower dams can speed implementation of technologies for fish protection and achieve economic goals. Spill of water over spillways is managed in the Columbia River basin to assist downstream-migrating juvenile salmon, and is generally believed to be the most similar to natural migration, benign and effective passage route; other routes include turbines, intake screens with bypasses, and surface bypasses. However, this belief may be misguided, because spill is becoming recognized as less than natural, with deep intakes below normal migration depths, and likely causing physical damages from severe shear on spillways, high turbulence in tail waters, and collisions with baffle blocks that lead to disorientation and predation. Some spillways induce mortalities comparable to turbines. Spill is expensive in lost generation, and controversial. Fish-passage research is leading to more fish-friendly turbines, screens and bypasses that are more effective and less damaging, and surface bypasses that offer passage of more fish per unit water volume than does spill (leaving more water for generation). Analyses by independent economists demonstrated that goals of increased fish survival over the long term and net gain to the economy can be obtained by selectively reducing spill and diverting some of the income from added power generation to research, development, and installation of fish-passage technologies. Such a plan would selectively reduce spill when and where least damaging to fish, increase electricity generation using the water not spilled and use innovative financing to direct monetary gains to improving fish passage.
\end{abstract}




\section{INTRODUCTION}

Juvenile salmon and other anadromous fish migrating from spawning areas in fresh water to the ocean often must pass through one or more hydropower dams. In the Columbia River basin, this may mean passage through up to nine dams on the Columbia River mainstem (Figure 1). For juvenile salmon originating in the Snake River tributary, this may mean up to eight dams. Although these circumstances are most prominent in the hydropower-rich Columbia River basin, similar situations face migratory fishes in other river systems such as in New England and maritime Canada, where rivers with Atlantic salmon are developed for hydropower, and in much of the U. S. east coast where American shad and other anadromous species use coastal rivers.

As the Columbia-Snake hydropower system is presently configured, downstream-migrating juvenile salmon have up to five possible routes for passage past dams. These are: (1) transit through the turbines, (2) diversion from turbine intakes by partial intake screens and through a fish bypass to the dam tailwater, (3) spill through spillways, (4) surface bypasses, including ice and trash sluices, and (5) transportation (Figures 2 and 3). Transportation refers to the collection of juveniles at a turbine bypass (route 2) of an upstream dam for trucking or barging them around all subsequent dams (Figure 4).

Studies have found that survival of juvenile salmonids differs by route of passage. Survival was generally highest for spillways, followed by turbine-screen bypass systems and then turbines (Schoeneman et al. 1961; Whitney et al. 1997; Muir et al. 2001). The estimated relative survival through the Snake River dams was highest at spill bays without flow deflectors for dissolved gas control (98\% to $100 \%$ ), followed by spill bays with flow deflectors (93\% to $100 \%$ ), turbine screenbypass systems (65\% to 99\%), and then turbines (87\% to 93\%) (Muir et al. 2001). Ploskey et al. (2001) compiled route-specific survival estimates from studies of fish tagged with PIT (passive integrated transponder) tags to characterize total effects (both direct and indirect mortalities) at The Dalles Dam where estimated relative survival of spring migrants was 96\%, 92\%, and $81-86 \%$, and summer migrants survival was $92 \%, 93 \%$, and $84 \%$ for spillbays, sluiceways, and turbines, respectively. The routes and their main benefits and problems for fish passage are briefly described below, with emphasis on spill.

\subsection{Turbines}

Juvenile salmon are carried through the turbine with the water flow, usually after some delay in the dam forebay for fish to descend to the turbine intakes. Turbines inflict damage to fish by several means: pressure changes, direct physical contact and damage through strike and grinding, cavitation, shear stresses, and strong turbulence (Cada et al. 1997). Because the circa 15\% mortality in passing through conventional Kaplan-type turbines used on the Columbia and Snake rivers was deemed the most severe of all in-river routes and unacceptable, a basin-wide goal of having at least $80 \%$ of juvenile migrants passing through non-turbine routes was developed (Whitney et al. 1997). 


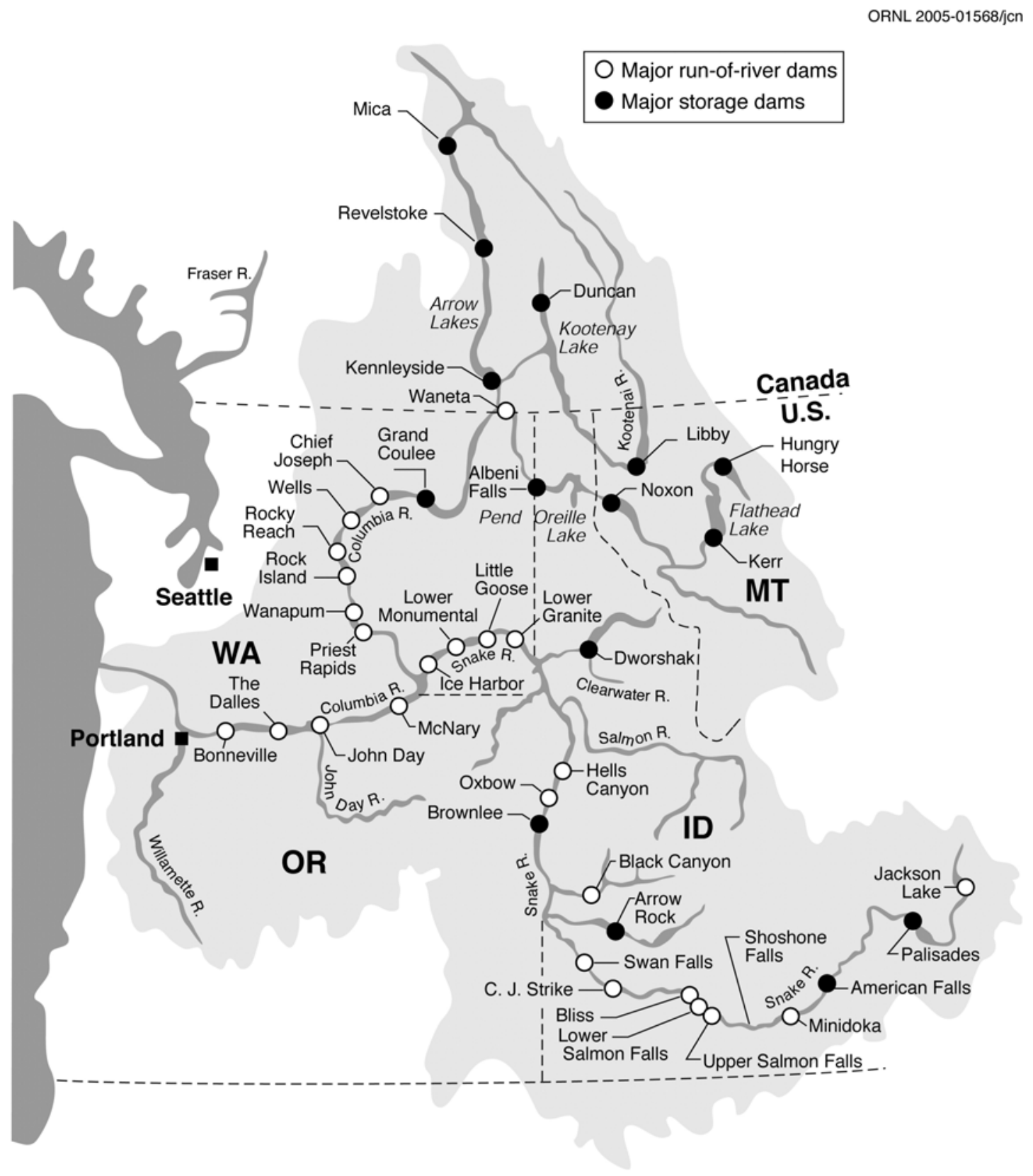

Figure 1. Major dams in the Columbia River Basin. Salmon have access to the bases of Chief Joseph Dam on the Columbia River and Hells Canyon Dam on the Snake River. In this area, Priest Rapids, Wanapum, Rocky Reach, Rock Island, and Wells are non-federal dams. (ORNL-2005-01588) 


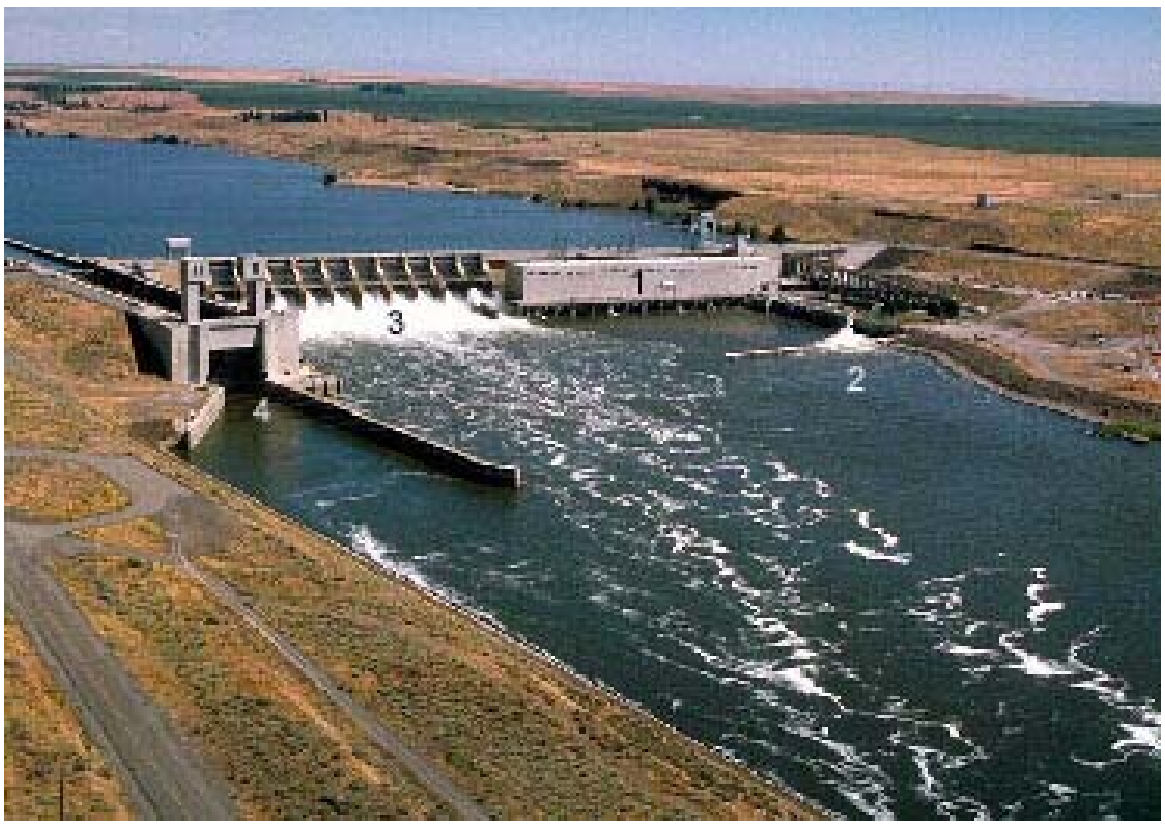

Figure 2. Passage options for downstream-migrating juvenile salmon at Columbia and Snake river dams, using Ice Harbor Dam on the Snake River as an example. 1- turbine passage, 2-turbine intake screens and bypass, 3- spill, 4- transportation by truck or barge. Ice and trash sluiceway is shown in Figure 3. (Photo courtesy of U.S. Army Corps of Engineers)

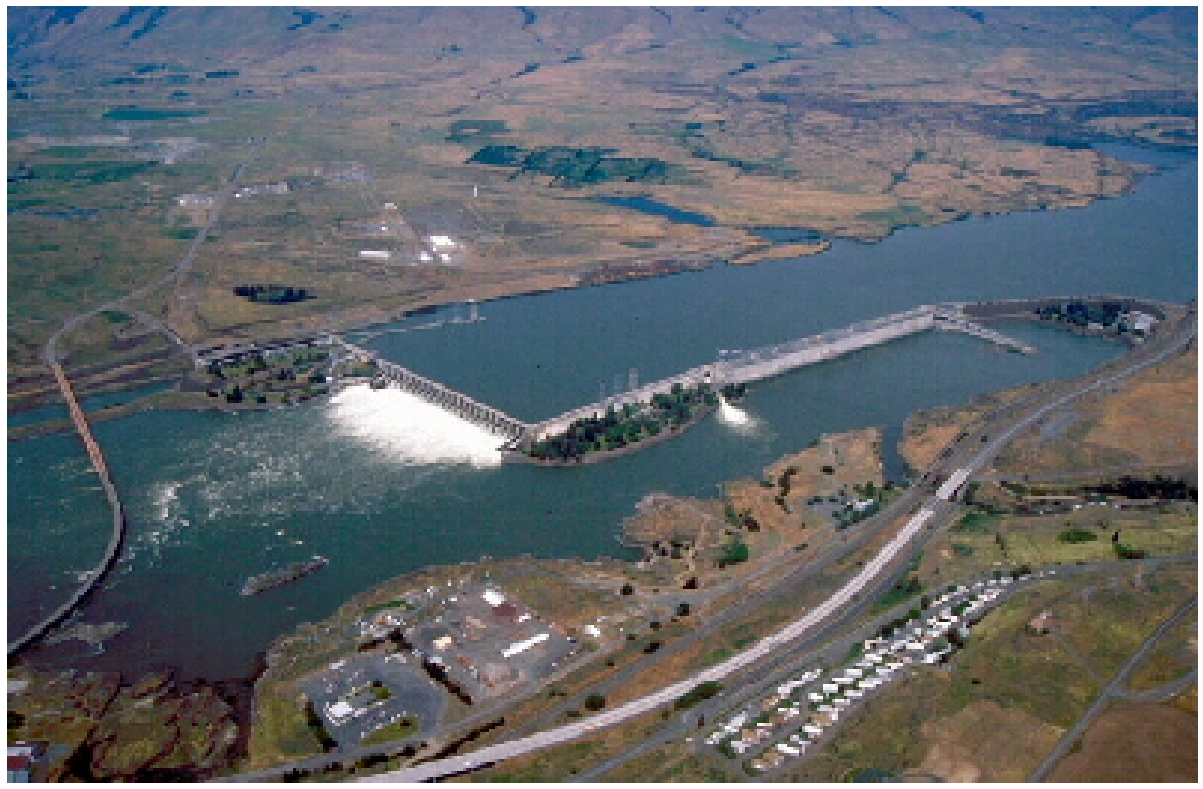

Figure 3. Photograph of The Dalles Dam, showing ice and trash sluiceway (small white plume next to the powerhouse) that has been effective as a surface bypass for juvenile salmon. (Photo courtesy of U.S. Army Corps of Engineers) 


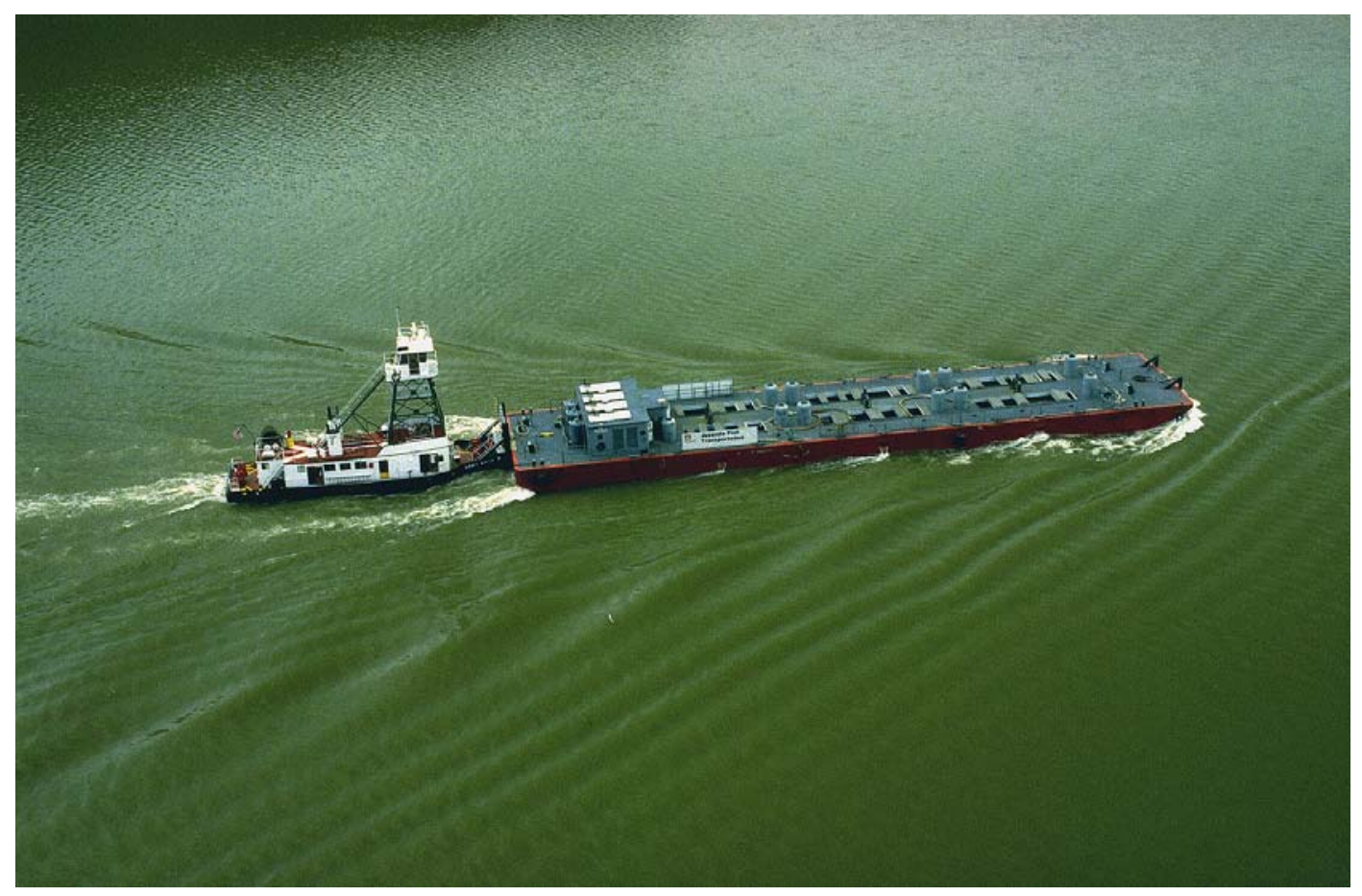

Figure 4. Transportation of juvenile salmon by barge around mainstem dams. (Photo courtesy of U.S. Army Corps of Engineers)

\subsection{Turbine Screens and Bypass}

Diversion of juvenile salmon from the turbine intake into a bypass system was developed in the 1970s as the first engineered alternative passage route (Figure 5). Early bioengineering studies of juvenile salmon behavior at the dams showed that surface-oriented juveniles entered deep turbine intakes (50-100 ft deep) reluctantly after delays in the forebay (the zone of the reservoir immediately upstream of the dam), then oriented to the ceilings of intakes, and entered the gate wells located at the tops of the intakes (Coutant and Whitney 2000). The gate wells, intended as slots for inserting solid barriers for excluding water from flowing into the turbines during maintenance, became refuges for many young fish. Nets were initially designed to rescue fish caught in the gate wells. Further reflection showed that this phenomenon could offer a useful route for bypassing the turbine. Vertical barrier nets were designed to guide fish in gate wells to passageways through the dam and thence to below the dam. There was extensive "replumbing" of dams to provide these passageways (for a fuller account, see Mighetto and Ebel 1994). Although survival within these bypasses is usually greater than $98 \%$, disoriented fish often were subject to intense predation where the bypassed fish are returned to the river. Ongoing research has led to several diversion screen types (e.g., traveling, extended-length), various designs of vertical barrier nets in gate wells, more fish-friendly piping, and outfalls below dams that minimize predation on the stressed fish on release. Most mainstem Columbia and Snake River dams in the Federal Columbia River Power System operated by the Corps of Engineers now have such screens installed. However, dams owned and operated by non-federal entities on the Columbia River mainstem (Priest Rapids, Wanapum, Rocky Reach, Rock Island, and Wells) do not have such diversion screens and rely entirely on spill of water over the dam spillways to convey fish. 


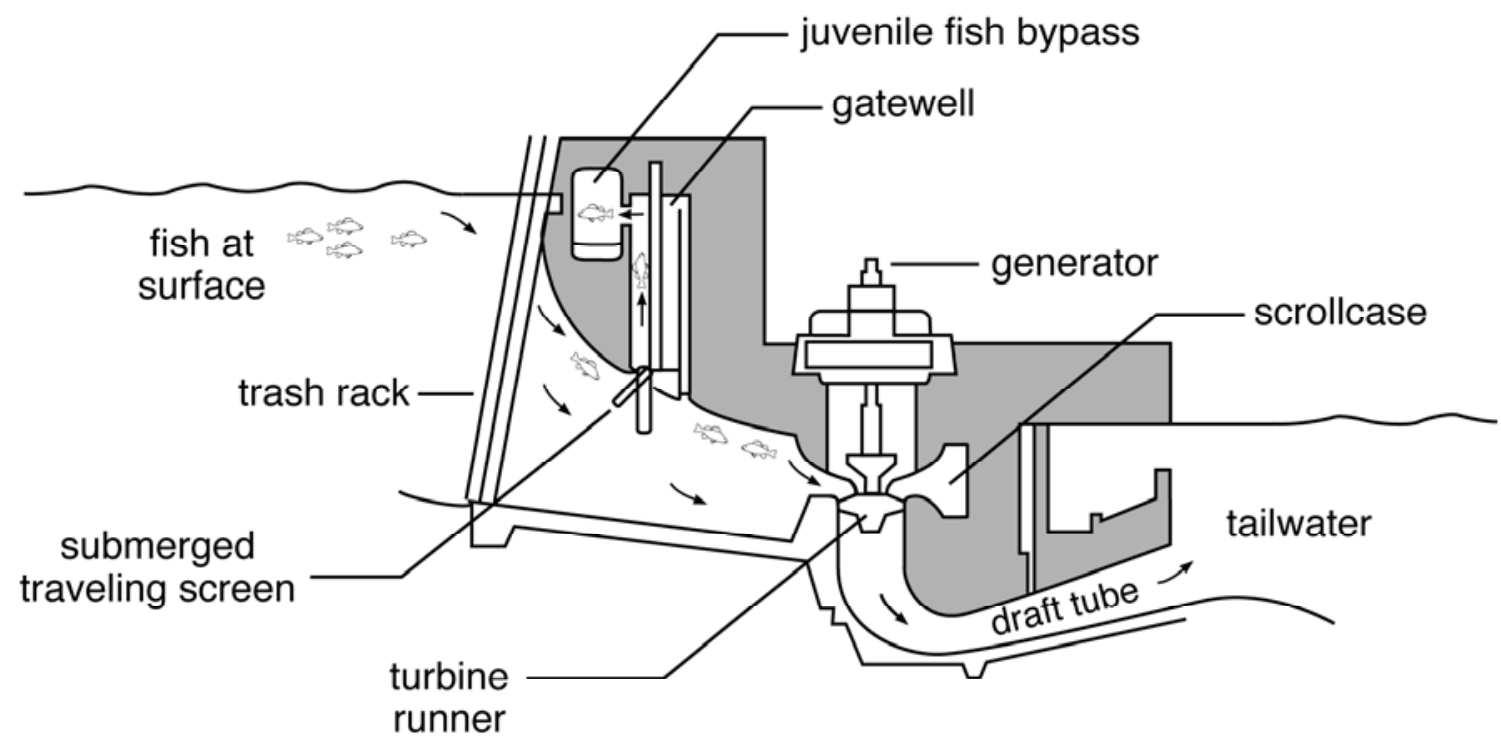

Figure 5. Cross section of a generalized hydropower dam in the Columbia River basin, showing a submerged screen to intercept fish heading toward the turbine and the bypass channel inside the dam that leads to the tailwater. (from Cada et al. 1997) (ORNL-96M-1484)

\subsection{Spill}

In any water year, some of the Columbia River basin water is spilled over spillways at the mainstem dams during the spring snowmelt (Figure 6). There is insufficient storage capacity in headwater storage reservoirs to retain all the initial melt water, and high river water stages necessarily result (although the peak flows contain much less water than prior to river regulation by storage dams). Powerhouses at the mainstem dams are not designed to accommodate these peak flows. Powerhouses use water for electricity generation up to their design hydraulic capacity and then the remainder of the flow is spilled ("involuntary spill"). In addition to this involuntary spill, there is voluntary bypass or "managed spill" at other times of year (or in addition to the amounts of involuntary spill in spring) to assist migration of juvenile salmon downstream (Whitney et al. 1997). How this "managed spill” is managed is the topic of this report.

Involuntary spill occurs in spring when many juvenile salmon are migrating downstream. This is because salmon out-migration has evolved to make use of the high flows and swift water velocities to speed the salmon out to sea. This involuntary spill at dams has been viewed as fairly natural and similar to fish passing over turbulent waterfalls such as Celilo Falls and Kettle Falls, now both inundated by hydropower dams. Resource agencies have considered spill to be the most normative route of passage, that is, most like natural migration with the bulk water flows.

As a seemingly normative passage route, spill was seen as a feature that could be managed to promote downstream passage even when there was not excess water in the river relative to hydropower capacity. Spill would be used for the benefit of downstream-migrating juvenile salmonids with the understanding that spill is usually the most benign and effective among the passage routes available. Whitney et al. (1997) reviewed 13 (3 steelhead and 10 salmon) estimates of spill mortality 


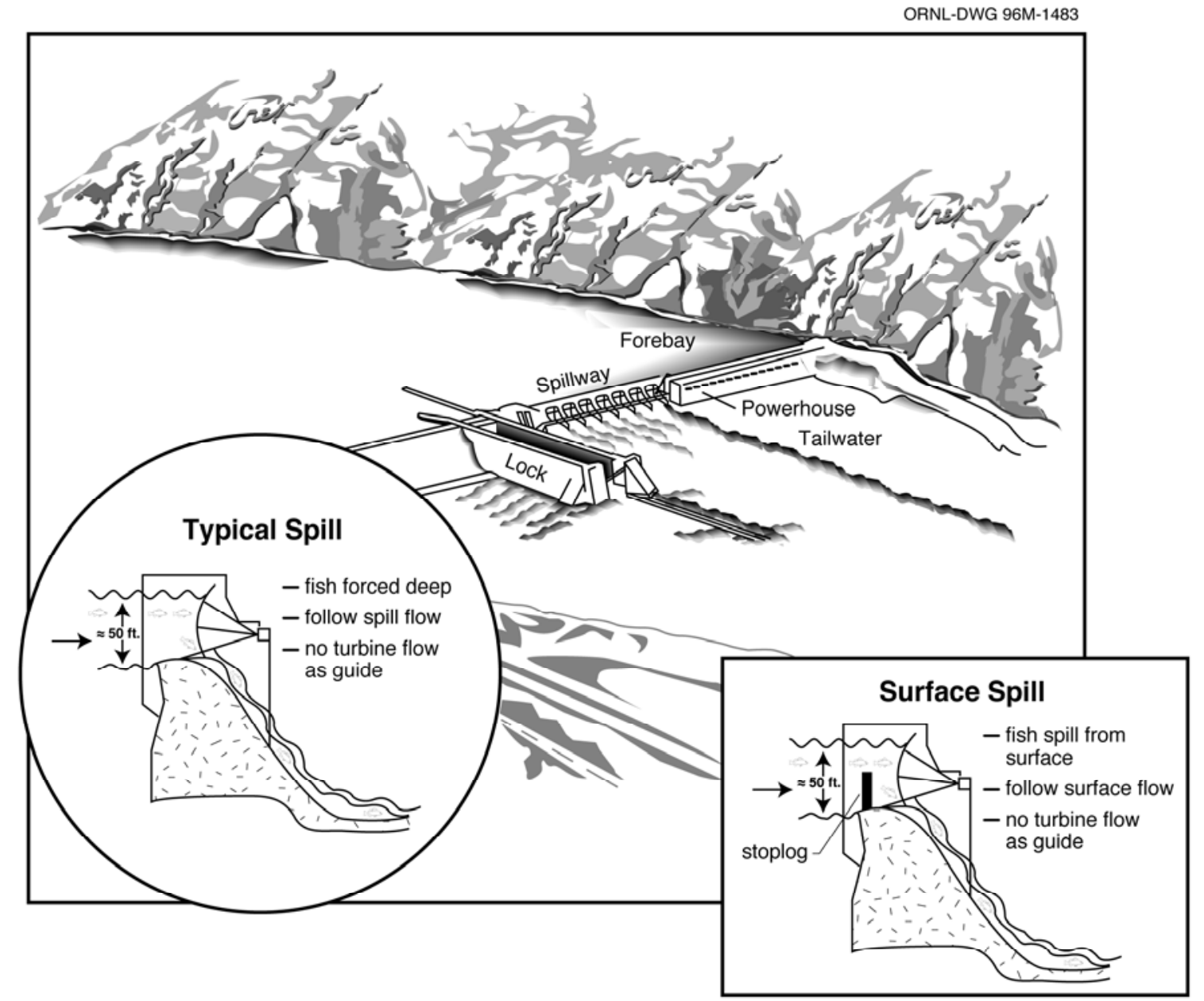

Figure 6. A generalized dam on the Columbia River, with two cross sections of the spillway showing typical spill at the base of a Tainter gate and surface spill. (from Cada et al. 1997). ORNL-96M-1483)

and concluded that 0 to $2 \%$ is the most likely mortality range for standard spillbays. Spill mortality may be greater at dams with spill deflectors and with localized hydraulic conditions such as back eddies or islands, that may provide habitat and refuge for predators (Iwamoto et al. 1994; Muir et al. 2001). Spill can also increase fish survival by shortening migration times through forebays, tailraces, and reservoirs, and by minimizing exposure to predators, stressful temperatures, and diseases (Snelling and Schreck 1994; Hansel et al. 1999, 2003; Shively et al. 1996; Beeman et al. 2003).

Managed spill became a preferred option for enhancing downstream fish passage at dams in years when there is little involuntary spill and in the medium-to-low flow seasons of years with typical river flows. In December 1988, the resource agencies and the Corps of Engineers developed a 10-year spill program (Fish Spill Memorandum of Agreement) for implementation at projects that were not equipped with adequate turbine bypass systems to achieve the $80 \%$ non-turbine passage goals. Declines in salmonids in the 1980s and early 1990s prompted the development of more aggressive spill management plans under the 1995 and 2000 NMFS Biological Opinions for operation of the Federal Columbia River Power System under the Endangered Species Act prepared by the National 
Marine Fisheries Service (now called NOAA Fisheries) of the Department of Commerce. Spill has been endorsed as a preferred route for dam passage by the Northwest Power Planning Council (now called the Northwest Power and Conservation Council) and it's Independent Scientific Advisory Board (NPPC 1999). Managed spill is particularly valued in summer when the underyearling fall Chinook salmon are migrating. Unlike the yearlings that migrate predominantly with high water in spring, the underyearlings migrate slowly in late spring and summer of their first year, growing as they migrate. It is believed that their safe passage in the warmer season is enhanced by flow augmentation (provision of extra water from upstream storage reservoirs) and managed spill. (NPPC 1994, NPCC 2003c)

Spill is the primary action for fostering fish passage in the Columbia and Snake rivers today. Managed spill has been stipulated at each Snake and Columbia river project as part of the NMFS (NOAA Fisheries) 2000 Biological Opinion. As noted above, spill is the only non-turbine route of passage designed into the non-federal, Columbia River mainstem dams. A complex spill regimen is selected each year for Columbia River mainstem dams, both as an intended strategy and as a base for analyzing alternatives. A "base case" for spill at the Columbia River mainstem dams for 2001 is illustrative (NPPC 2001):

Federal dams:

Bonneville Dam - 75 Kcfs (day) and 90 Kcfs (night)

The Dalles Dam - 40\% of river flow spilled (continuous for 24 hours)

John Day Dam - 30\% spill (12 hours at night)

McNary Dam - No spill; 50\% fish transport

Non-Federal Dams:

Priest Rapids Dam - 61\% spill (24 hours)

Wanapum Dam - 43\% spill (24 hours)

Rock Island Dam - 31 Kcfs spill (24 hours)

Rocky Reach Dam - 15\% spill (24 hours)

However, faith in spill may be misguided, because spill is becoming recognized as less than normative ecologically, and socially expensive in terms of foregone power production. Ecologically, spillways are poor matches for natural migration paths (Coutant and Whitney 2000). Spill generally occurs from deep-water intakes below the normal surface fish migrations, resulting in delayed passage as fish seek the openings. Delays increase the likelihood of losses in the reservoir due to predation, and extend the exposure times to warm water in summer. Passing over spillways causes physical damages to fish from high velocities, severe shear on spillway surfaces, pressure changes more severe than in turbine passage high turbulence in tail waters, and collisions with baffle blocks that lead to disorientation and predation (Bell and Lacy 1972; Ruggles and Murray 1983; Absolon et al. 2000; Muir et al. 2001; Carlson and Duncan 2003; Nosmardeau Associates et al. 2003). As more information has become available, the general superiority of spill at all dams is being questioned. Although some spillways are fairly benign, other spillways have been shown to induce long-term mortalities comparable to those from passing through turbines.

It is known that spill, especially so-called "summer spill", is economically expensive. Summer spill is mostly in July and August when spill is used for benefit of late-migrating fall Chinook salmon, which originate mostly in the Snake River. Staff of the Northwest Power and Conservation Council (Council) presented preliminary analyses of the costs and fish population effects of summer spill for the federal power system (NPCC 2003a, 2003b). They estimated that ending August bypass (managed) spill in normal flow years would generate about \$38 million per year in new power revenues with negligible fish impacts. The Bonneville Power Administration likewise examined the benefits of ending summer bypass spill in mid-August (two weeks early relative to the current ending at the end of August) at Bonneville, The Dalles, John Day, and Ice Harbor dams in average years 
(Cooper 2003). They estimated that annual power revenues would increase by $\$ 17$ million. Summer spill is especially expensive because of increased load demand and increased value of each megawatt of power generated in summer. These preliminary estimates culminated in proposals to reduce or eliminate summer spill in 2004-2006. In section 2 we consider the societal costs of managed spill in more detail.

\subsection{Surface Bypasses}

The fourth option for passing juvenile salmon at dams is the surface spill or surface bypass. It is an option that has developed an enthusiastic following because of its potential for collecting migrants in their normal near-surface migration location (thus minimizing migration delays), utilizing the normal migratory behavior of the fish to enter a bypass rather than artificial screens or other diversion devices, and (most importantly) passing large numbers of fish per unit volume of water, making it more efficient of water use than spill. The initial "surface bypasses" were ice and trash sluiceways designed to pass floating material that would otherwise accumulate behind dams (Whitney et al. 1997; Figure 3). Observations in the 1950s indicated that these routes were used by an inordinately large number of juvenile salmon for the volume of water passed. The sluice at The Dalles Dam was especially effective and is a major fish passageway today, even without major modification. As a result of these observations, "stop-log" tests were run, in which temporary gates (normally used for spillway maintenance) were lowered upstream of the typical spillway's tainter gates but allowing several feet of water to pass over or near the top (Figure 6). These tests confirmed the natural tendency of smolts to pass over a surface weir and to do so in numbers larger than the numbers passing in normal deep spill. However, blockage of spillways and engineering concerns for the structural integrity of the dams prevented routine installation of such surface-flow weirs.

Extensive research and testing within the last decade has developed functional surface bypasses. A spill configuration at Wells Dam (spillways located above the turbines) indicated that greater than $90 \%$ of the downstream migrants could be passed in $10 \%$ of the water flowing through the dam. Although not truly a surface bypass, the success demonstrated that shallower water and fish could be diverted above turbines. This concept was tested with prototype bypasses at Lower Granite and Bonneville dams and at the Cowlitz Falls Dam on the Cowlitz River, but with only moderate to poor success. More recently, a Removable Spillway Weir applicable to many sites was tested at Lower Granite Dam (Figures 7 and 8) and a Corner Collector was constructed at Bonneville Dam (Figure 9). These successful attempts will be discussed in more detail Section 3.5 of this report. Despite their demonstrated efficacy, surface bypasses are often expensive to develop, test, and install.

\subsection{Transportation}

In addition to these four routes of passage through a single dam, there is the transportation, by truck or barge, of juvenile salmon from upstream dams to the freshwater tidal estuary below Bonneville Dam (Figure 4; Giorgi et al. 2002). Because survival during passage through multiple dams was believed to be low (cumulative 15\% loss at each of many dams, if passage is through turbines), a method for avoiding many mainstem dams was proposed and implemented in the 1970s. Juvenile migrants have been collected from the screen bypasses at the upstream Lower Granite and Little Goose dams on the Snake River and at McNary Dam on the Columbia River and moved by truck or barge past the subsequent downstream dams. Research has shown that such transportation is of little benefit for smolt-to-adult survival during much of a normal year. However, in-river survival of 
downstream-migrating smolts is low in late summer and during low-flow years; transportation at those times is more likely to be a real benefit to the fish population. Recent analyses of returns of fall Chinook salmon PIT-tagged as juveniles in in-river and transported lots indicates that transportation is not benefiting fall Chinook survival to adults (JTS 2004).
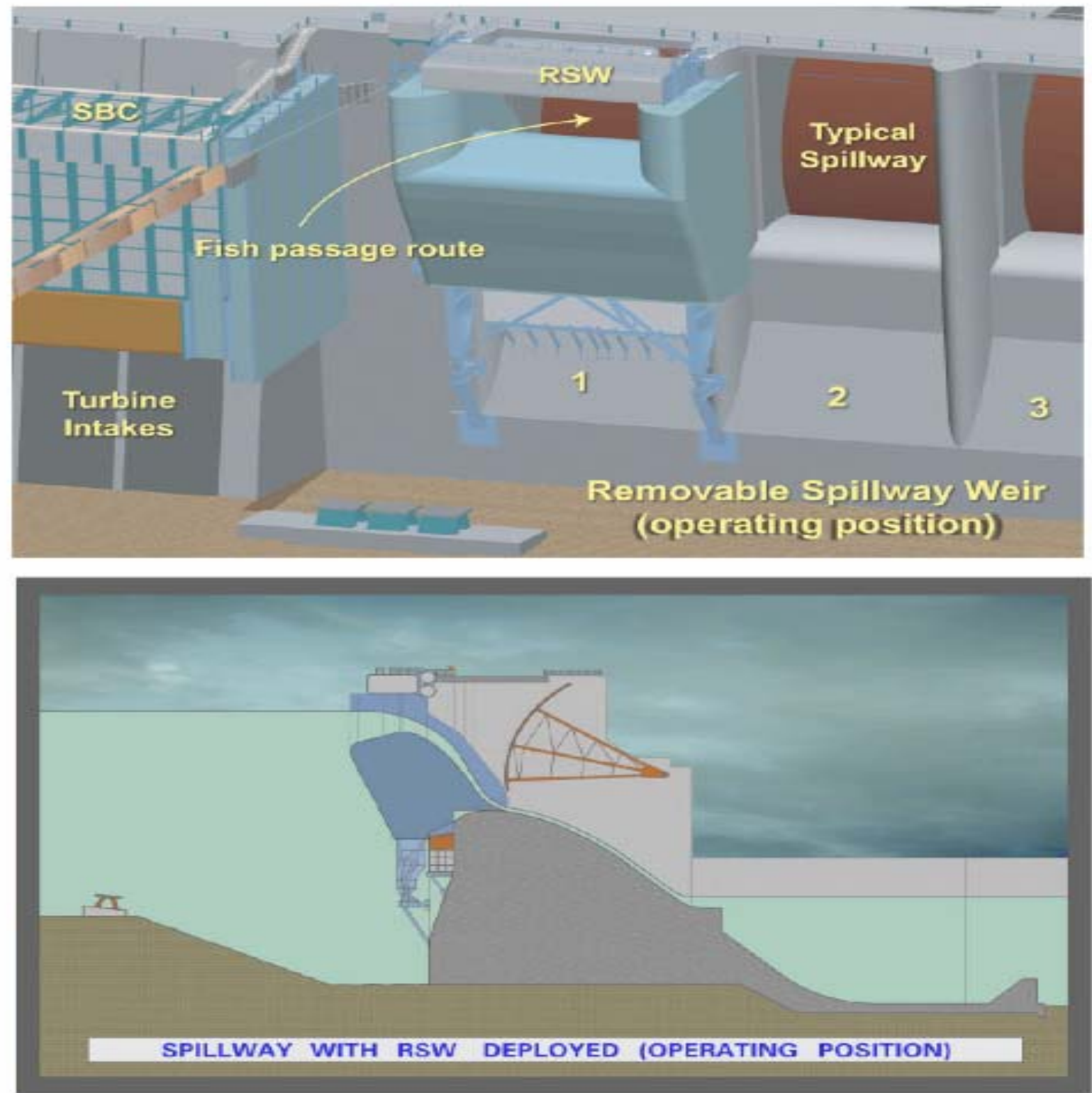

Figure 7. Diagram of the Removable Spillway Weir developed by the U. S. Army Corps of Engineers. (Courtesy of U.S. Army Corps of Engineers) 

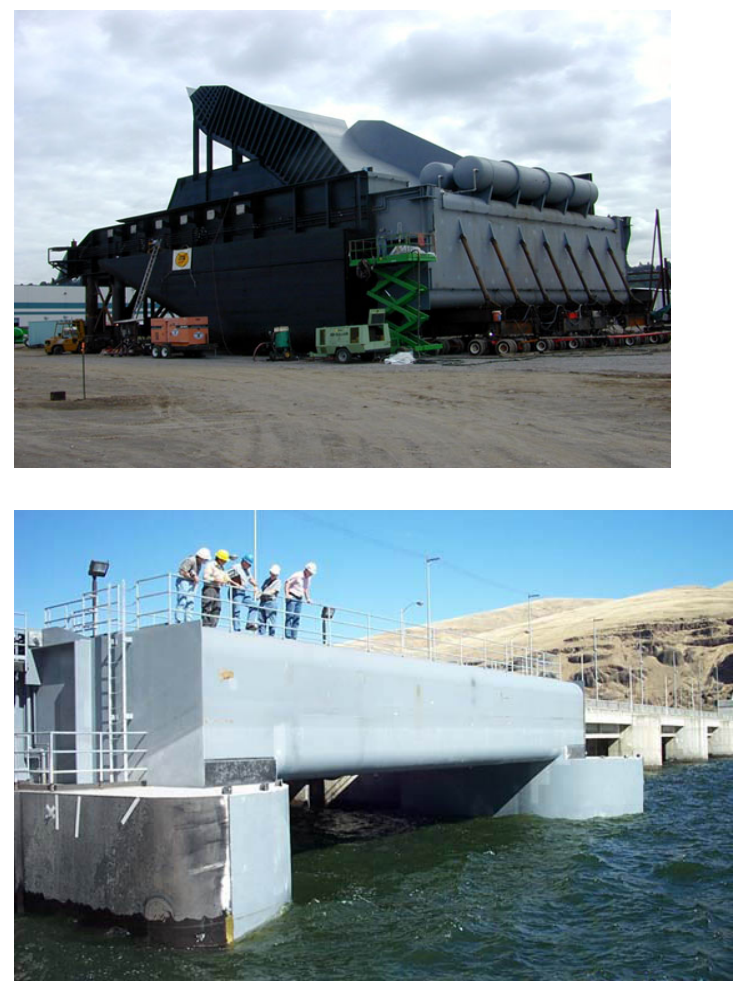
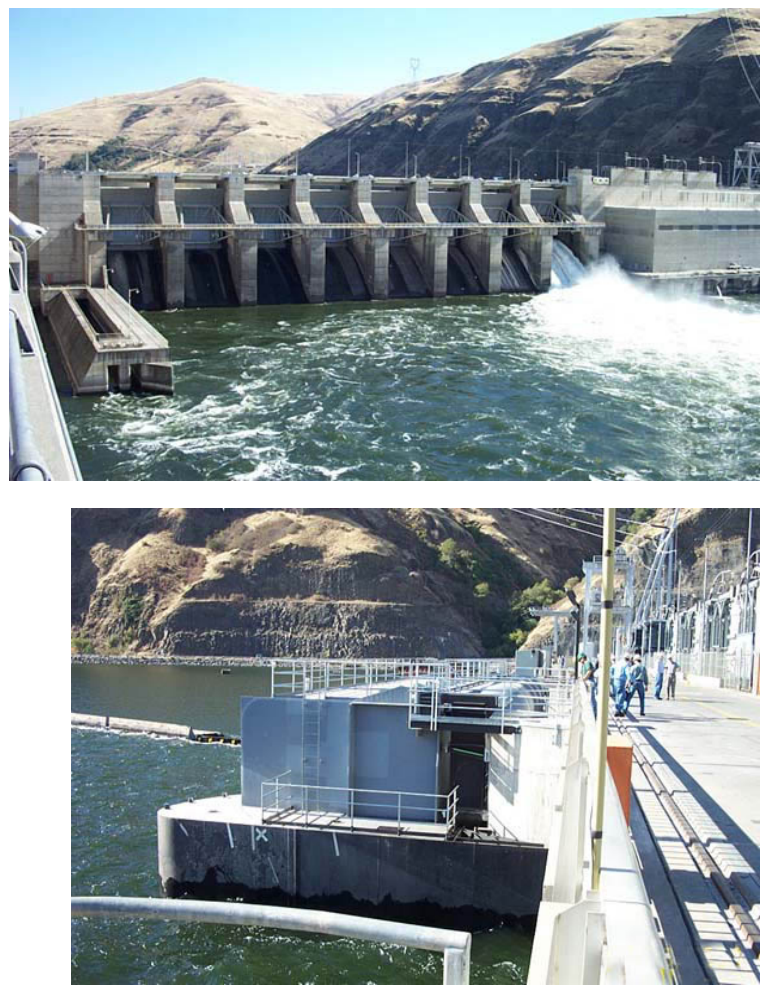

Figure 8. Photos of the Removable Spillway Weir at Lower Granite Dam. Counter clockwise, from upper left: RSW on land; forebay view of RSW in place; RSW in place, view from the dam; RSW spilling water at the right-hand spill bay. (Photos courtesy of U.S. Army Corps of Engineers)

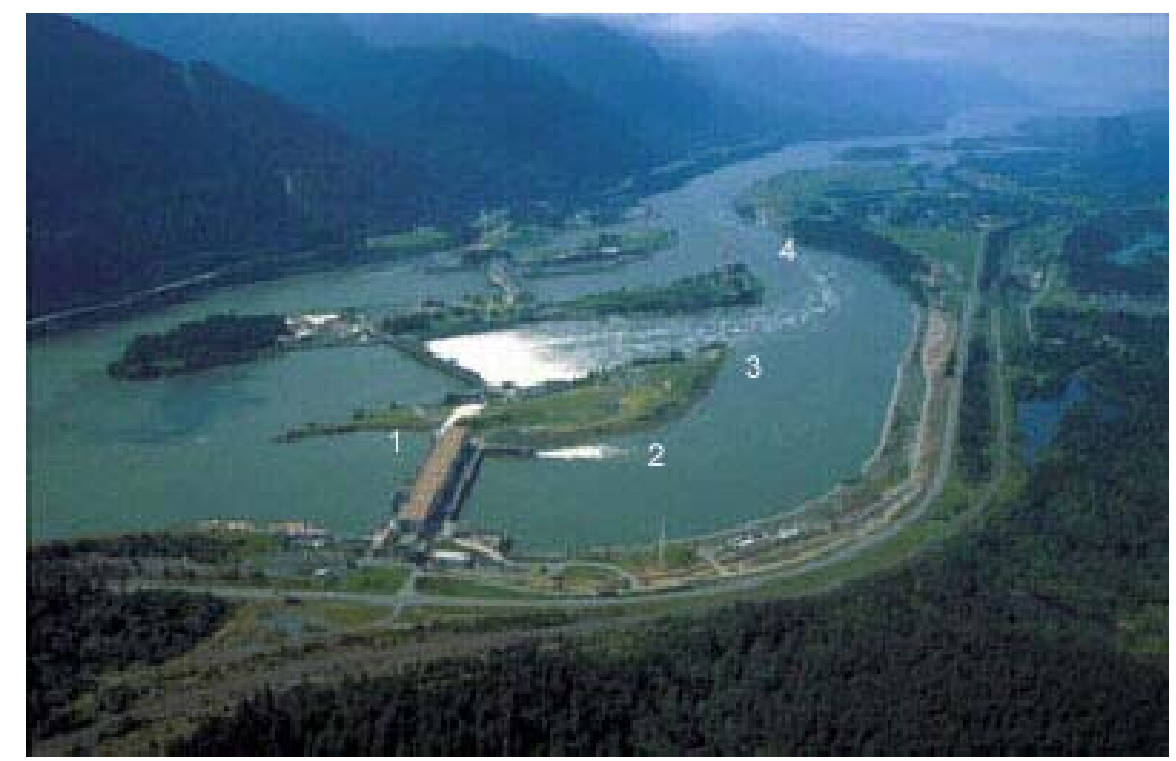

Figure 9. Bonneville Dam showing locations of the Corner Collector (1), original Corner Collector outfall (2), new Corner Collector outfall location (3) and the outfall location for the juvenile salmon turbine bypass. Photo was taken before both outfalls were extended. (Photo courtesy of U.S. Army Corps of Engineers) 


\subsection{Hydropower Mitigation}

Overall improvement in the survival of juvenile migrants through the hydropower system is the goal of federal, state, tribal, and many private organizations. This improvement can be accomplished by several means, as described further below. The survival of fish passing through turbines can be improved with better, more "fish-friendly" turbine designs. The Corps of Engineers and the Department of Energy's Hydropower Program have pursued this avenue. Alternatively, intake screens and the bypass systems to which they deliver fish can be improved. The Corps has conducted research and development on extended-length screens and other screen and bypass improvements. In another approach, the efficacy of spill can be improved, largely by matching managed spill regimes to the timing and location of migrants, such as through selecting appropriate spill bays, spill flows, and distribution of flows in day and night. Surface bypasses, the newest engineered technology, can be improved in many ways including location, design, and operation. Surface bypasses are only recently being installed as operational devices, even though ice and trash sluices continue to function well in this regard (Whitney et al. 1997).

Rather than being considered alternatives, each of these approaches has been pursued in the Columbia River basin simultaneously. The strategy of planned redundancy has been effective in bringing juvenile salmon survival to nearly the level it experienced prior to the development of the hydropower system (Williams et al. 2001). The downside is that pursuit of all four strategies at once has been very expensive and the duration of effort for installation of any improved technology at each dam has been prolonged. Simultaneous pursuit of several mitigation strategies has made it difficult to assign longterm, multi-year improvements or degradation to any one technology, and to conduct hypothesis testing for improvement due to each technology.

Because of the high monetary cost of spill for fish passage in terms of foregone power production, a formal proposal was presented by BPA and the Corps of Engineers in early 2004 to eliminate or reduce spill at federal mainstem hydropower dams in the Columbia and Snake rivers. The proposal was extremely controversial (a chronology of events is summarized below). Attempts by the operating agencies of the Federal Columbia River Power System (mainly the Corps of Engineers and Bonneville Power Administration) to reduce summer spill in 2004 and produce electricity and income from the water not spilled led to lawsuits and denial of the proposal by the court. The controversy has pitted apparent economic interests against apparent fisheries interests. Although settled for 2004, the issue is bound to resurface. In fact, in an unrelated lawsuit, the U.S. District Court for Oregon on June 10, 2005 ordered the continuation of spill at the four lower Snake River dams and McNary, June 20 through August 31 to the exclusion of power generation (except for facility requirements) (National Wildlife Federation versus Oregon, CV 05-23-RE).

This paper evaluates some of the more technical aspects of the controversy of reducing managed spill, highlighting the trade-offs among routes for fish passage and between economics and successful fish migration. Set apart from rhetoric and traditional animosities, the technical evidence provided here suggests win-win approaches that can enhance long-term fish survival and increase the economic benefits of hydropower. 


\section{SOCIETAL COSTS OF SPILL FOR FISH PASSAGE}

Spill is an anomaly in several respects for its continued use or further implementation to enhance fish passage. On the one hand, it is the easiest of all fish-passage alternatives to deploy. A decision can be made to open spill gates and the result can be obtained within minutes to hours. As has been the case, requirements for managed spill can be stipulated in policy documents such as the NOAA Fisheries' Biological Opinions, without delays to conduct research and development. It seems inexpensive when viewed in the short run.

However, of all the passage options, spill is the most costly alternative to society in the long run in terms of foregone power production and the need to generate the power elsewhere. The Bonneville Power Administration has recently made several estimates of the lost revenue from foregone power generation in the Federal Columbia River Power System (that does not include the non-federal dams, where spill is the main route of fish passage). In a January 2004 estimate of a typical year for water availability, their analysis concluded that eliminating managed spill for fish passage at Columbia River dams in July and August would reduce adult Chinook salmon returns by 19,000 fish, but gain the Bonneville Power Administration about \$77 million in revenue it now forgoes when it spills water over dams. For a range of water years, the revenue foregone was \$55-92 million. ${ }^{1}$ Eliminating managed spill at Ice Harbor Dam alone on the Snake River would enable BPA to reduce spill costs by \$13 million to \$22 million annually because more of the river flow could be used to generate power. BPA estimated $\$ 1.2$ billion in foregone 1978-2001 hydropower revenues in the Federal Columbia River Power System due to spill for fish.

To put these monetary amounts in perspective, the hydroelectric dams on the Columbia and Snake rivers produce an average of about 18,500 megawatts of electricity annually, which is about $75 \%$ of the Northwest's electricity supply (CRSOR 1991). This amounts to 444,000 Megawatt-hours per day (although the production is not continuous either daily or hourly). At the current pricing average of $\$ 36$ per megawatt hour, this amounts to revenue of $\$ 15,984,000$ per day or $\$ 5,834$ million per year. Thus, the lost generation of $\$ 77$ million per year from managed spill for fish is slightly over $1.3 \%$ of the average annual revenue from hydropower operations (range $0.9 \%$ to $1.6 \%$ for a range of water years). Although small in percentage of hydropower revenues, the monetary amounts related to managed spill are large in comparison to the costs of fish passage facilities, as discussed further below.

The long-term cost effectiveness of spill has come under scrutiny because of the apparent long-term expense of managed spill (Table 1; NPCC 2003a, b, 2004), coupled with coincidence of extremely low river flows in 2001 and the disruption of energy markets in 2000-2001 with deep financial ramifications for BPA (see Council's account of the events of 2000-2001 in the main body of NPCC 2004). In addition, federal law mandates cost effectiveness of fish and wildlife measures. Section §4(h) (6) (C) of the Northwest Power Act (Northwest Power Act, 94 Stat. 2710, as amended by Pub. L. 104-206 §5124(h)(6)(C) §512(4)(h)(10)(D)(vi) September 30, 1996110 Stat. 3005) requires that the Northwest Power and Conservation Council, as a policy-setting organization for fish and wildlife mitigation of hydropower, "will utilize, where equally effective alternative means of achieving the same sound biological objective exist, the alternative with the minimum economic cost." Section $\S 4(\mathrm{~h})(10)$ (D) (vi) states: "in making its recommendations to BPA, the Council shall determine whether the projects employ cost-effective measures to achieve program objectives.” The Council has

\footnotetext{
${ }^{1}$ BPA has chosen to normalize on costs rather than megawatts because the value of electricity varies within a day, seasonally, an annually according to demand and availability. BPA applied the price of \$36/Megawatthour, which it derived from AURORA, a market pricing model used extensively in the region. The pricing range used by BPA was \$15-42/MWh in July and \$30-48/MWh in August.
} 
Table 1: Annual Average Cost and Energy Loss of Managed (Bypass) Spill for the Federal Columbia River Power System (river flows at each project are 50-year averages; assumes power operations anticipated for 2006; costs in 2004 dollars). (from NPCC 2005, Appendix O)

\begin{tabular}{lcc}
\hline \multicolumn{1}{c}{ Project/Season } & $\begin{array}{c}\text { Cost } \\
\text { (Millions \$) }\end{array}$ & $\begin{array}{c}\text { Energy Loss } \\
\text { (MW-Hours) }\end{array}$ \\
\hline John Day/Summer & 31.1 & 766,810 \\
John Day/Spring & 29.6 & 791,895 \\
Ice Harbor/Spring & 28.6 & 742,361 \\
The Dalles/Spring & 27.5 & 735,028 \\
The Dalles/Summer & 25.6 & 625,399 \\
Bonneville/Summer & 23.3 & 560,671 \\
Bonneville/Spring & 20.7 & 542,524 \\
McNary/Summer & 12.2 & 306,571 \\
Ice Harbor/Summer & 11.8 & 292,441 \\
McNary/Spring & 10.6 & 276,784 \\
Lower Monumental/Spring & 8.8 & 233,917 \\
Little Goose/Spring & 4.1 & 109,644 \\
Lower Granite/Spring & 3.3 & 87,504 \\
Total (energy loss in average megawatts) & 237 & 693 \\
\hline
\end{tabular}

responded to these circumstances with 2003 Mainstem Amendments to the Columbia River Basin Fish and Wildlife Program (NPCC Council Document 2003-11, Page 19) that call for "a rigorous evaluation of the biological effectiveness and cost of spillway passage" to "determine if it is possible to achieve the same, or greater, levels of survival and biological benefit to migrating fish as currently achieved while reducing the amount of water spilled, thus decreasing the adverse impact on the region's power supply.”

Concurrent with these concerns over the cost-effectiveness of spill for fish passage in the Columbia River basin, the Department of Energy has espoused a goal of a 10\% increase in hydropower production nationally over 10 years (Cada et al. 2004; Sommers et al. 2005.). Hydropower is the most fully implemented of the many renewable energy resources, which also include wind, geothermal, and solar energy. Hydropower has many societal benefits compared to other energy sources; for example, water can be stored for use when needed, hydropower is easily turned on and off to meet fluctuating electricity demands, there are no emissions of carbon dioxide that would fuel the greenhouse effect and global warming (although methane can be an issue for deep storage reservoirs), dams and reservoirs create other benefits such as recreational boating and reliable municipal water supplies. Because it is so fully implemented, however, there are few environmentally acceptable locations for new hydropower dams. Therefore, improvement in the production efficiency of existing hydropower facilities is a logical goal. More efficient water utilization for power production is, therefore, a clear objective. For much of the Columbia River basin where hydropower is dominant power supply, this objective means using less managed spill. 


\section{STRATEGIC ALTERNATIVES TO MANAGED SPILL}

If not managed spill, then what? Alternatives to managed spill for fish passage are being developed. This section briefly describes several options. In some cases, these alternatives are highly engineered solutions, whereas in others they derive from observations of the high fish passage effectiveness (number of fish passed per unit volume of water) from existing or readily modified structures.

\section{1 $\quad$ Fish Friendly Turbines}

One avenue for reducing managed spill for fish and capturing the additional generating power from water otherwise spilled is through use of advanced turbines that are less damaging to fish passing through them (so-called "fish-friendly" turbines). In principle, all the river flow could be passed through turbines if the mortality rates through turbines are equal to or less than those experienced by fish in spill. Both the Corps and the Department of Energy have supported development of such turbines (USACE 2004; Cada et al. 2004; Sale et al. 2006). One of the first of these new turbine designs, the Minimum Gap Runner Turbine (MGR), was tested in prototype at Bonneville Dam for both mechanical and biological effectiveness (USACE 2004). Among other improvements, this design sought to minimize the gaps between the turbine's blade (runner) and both the hub and the surrounding wall. This approach was taken because many injuries have been attributed to fish being squeezed through these gaps, where physical abrasion and shear forces are intense.

Another test of an advanced-design runner was carried out at Wanapum Dam in Spring 2005 (Brown and Garnant 2006; Normandeau Associates, Inc. 2006). Compared to the existing turbines, the new turbine has a larger runner diameter, greater output rating (111.8 MW instead of 89.5 MW), and greater hydraulic capacity (18.5 kcfs instead of $17.8 \mathrm{kcfs}$ ) (Figure 10). Grant County PUD completed the installation of the advanced MGR turbine into Unit 8. Compared to a conventional Kaplan turbine, the advanced turbine is expected to have lower values for several potential fish injury mechanisms: shear stress, turbulence, cavitation, and grinding. On the other hand, the MGR has more blades (6 vs. 5) and more wicket gates (32 vs. 20) than the Kaplan turbines at Wanapum, which might increase the potential for strike injuries. If fish passage survival through the advanced turbine meets decision criteria for environmental performance (fish survival through the advanced turbine is at least as good as through the existing turbine), then installation of the next 9 advanced turbines would proceed on a schedule of approximately 1 per year. If all 10 conventional Kaplan turbines are replaced by MGRs, total power output from the Wanapum Dam would increase from 895 MW to 1118 MW (25\% increase) and the total rated hydraulic capacity would increase from $178 \mathrm{kcfs}$ to $185 \mathrm{kcfs}$ (a 3.9\% increase). Design, installation, and testing of the advanced turbine at Wanapum were accomplished with the assistance of the U.S. Department of Energy's Wind and Hydropower Technologies Program.

Installation and preliminary engineering performance testing of the MGR at Wanapum Unit 8 were completed by mid-February 2005 (Figure 11). Performance results were reported by Normandeau Associates, Inc, et al (2006). Fish survival tests, using sensor fish, balloon-tagged fish, and PITtagged fish were carried out in February, March, and April 2005. Tagged fish were passed through two turbines (the new MGR in Unit 8 and the conventional Kaplan turbine in Unit 9), 3 intake slots in each turbine (A, B, and C), two intake release depths (10 ft and $30 \mathrm{ft}$ ), and 5 turbine flows $(9,11,15$, 17 and $18.5 \mathrm{kcfs}$ ). A total release of 8,960 balloon-tagged fish and 1,000 sensor fish were used to quantify direct mortality associated with turbine passage. The results of these extensive environmental performance tests indicated that the overall weighted fish survival was statistically the same in the new and the existing units (approximately 98\%; Normandeau Associates, Inc., et al. 2006). That performance satisfied the FERC license requirements and will enable more advanced turbines to be installed. The new unit also produced a $14 \%$ increase in power output and a 3\% 


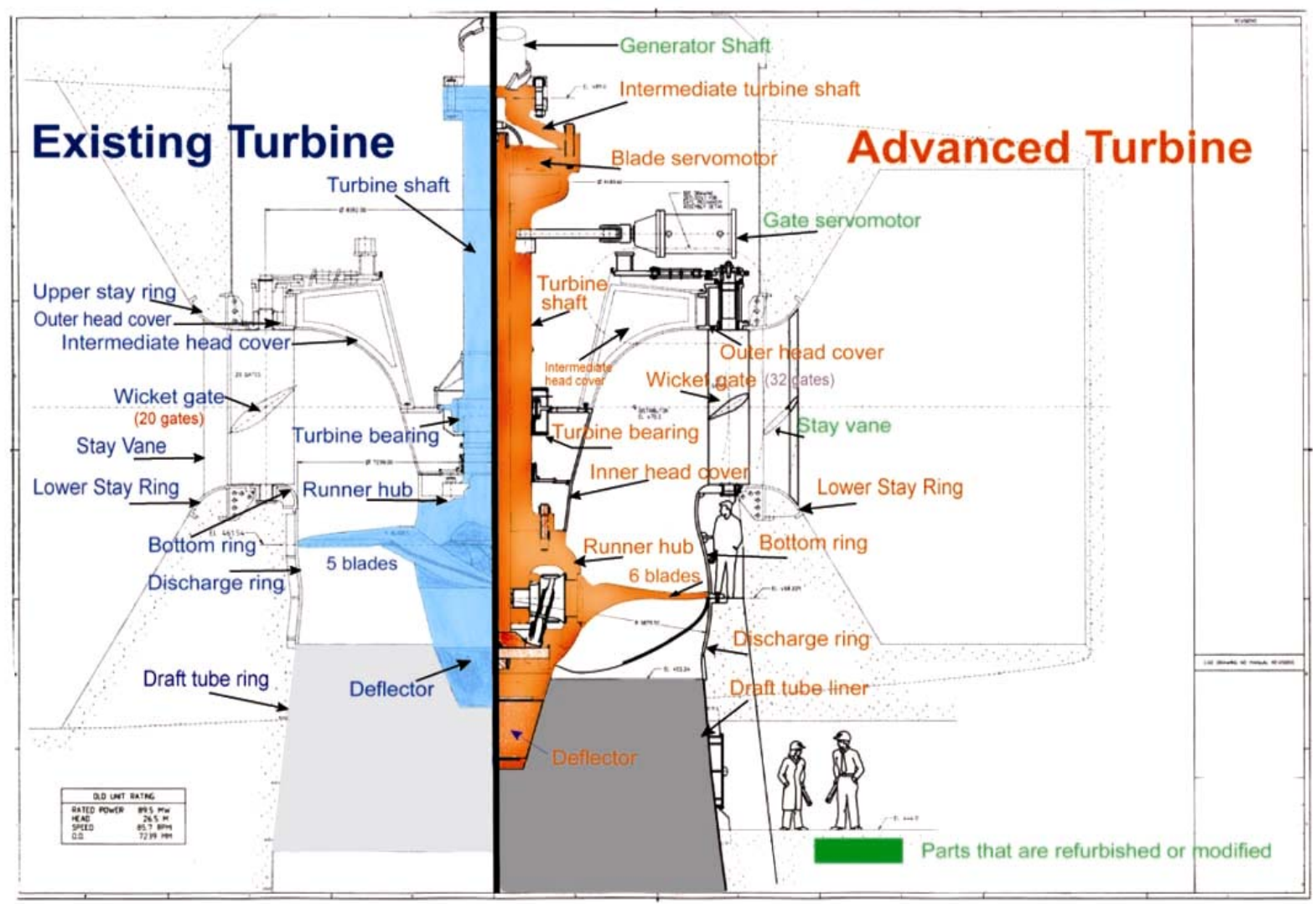

Figure 10. Comparison of the design features of the existing (Unit 9) and new (Unit 8) runners at Wanapum Dam. (Figure courtesy of Public Utility District No. 2 of Grant County, Washington).

increase in water use efficiency. More performance testing will occur at Wanapum Dam as more of the advanced runners are installed. If the Wanapum tests are conclusive in demonstrating a major benefit for fish of this design, it is the Utility District's intent to significantly reduce spill and increase hydropower generation (spill is currently the primary passage route). Previously, spill requirements for the spring and summer periods were as high as 32\% of the river flow at Wanapum Dam and 60\% of the river flow at Priest Rapids Dam (Brown and Garnant 2006).

The potential success of installing fish-friendly turbines depends on the results of prototype installation and testing. Federal cost-sharing from the U.S. Department of Energy's Hydropower Program has been an important part of the prototype testing up to this point (Sale et al. 2006); if the DOE Program is closed out as proposed, industry will have to carry the full cost and development risk of new turbines. 


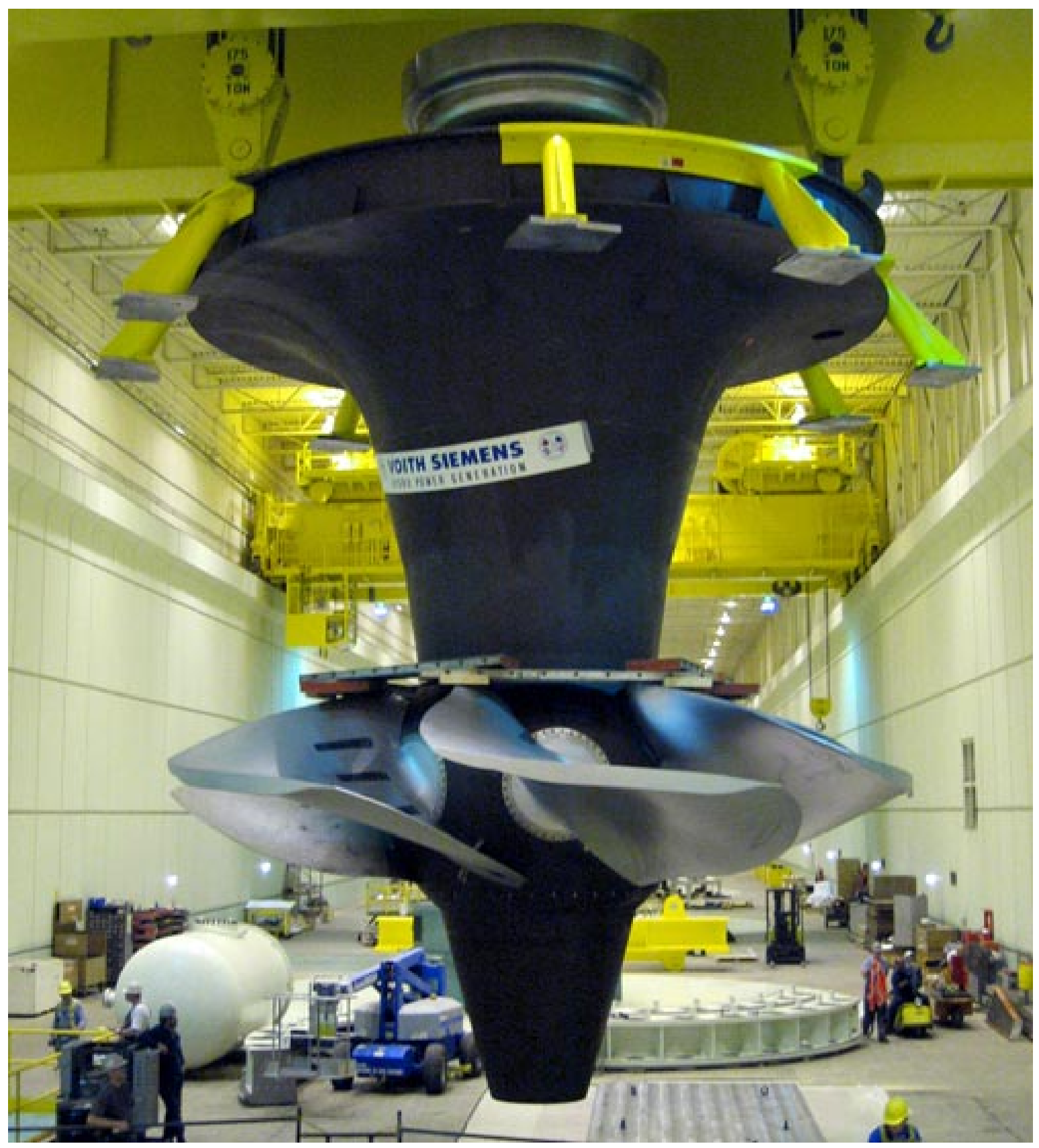

Figure 11. Advanced-design runner installed at Wanapum Dam Unit 8 in 2005 (Photo courtesy of Public Utility District No. 2 of Grant County, Washington). 


\subsection{Improvements to Turbine Bypasses}

The main problems with turbine screening and its associated fish bypasses (the standard approach for federal projects) have been the incomplete collection of fish in turbine intakes and high predation rates on juvenile salmon at the points where fish are returned to the river (Whitney et al. 1997). Although juvenile salmon tend to enter turbine intakes near the ceiling (Coutant and Whitney 2000) many are not diverted by the intake screens, which only partially occlude the turbine entrance. Thus, there has been a program to extend the lengths of intake screens (extended-length screens; e.g., Brege et al. 2000). At the outfall, predators such as northern pikeminnow, gulls, pelicans, and cormorants congregate at the outfalls and devour the fish. The fish are vulnerable because of their high concentration, disorientation from being screened and conveyed, and the often slow-moving water into which they are released. There are continuous efforts to upgrade these outfalls to make them less hazardous to fish (Shively et al. 1996). Notable among the efforts was the 2-mile-long outfall pipeline below Bonneville Dam, which conveys fish collected at the turbines to a point downstream where swift currents make predatory activities more difficult than in the dam's immediate tailwaters (Figure 9).

\subsection{Ice and Trash Sluiceway at the Dalles Dam}

Fortuitously, the surface ice and trash sluiceway at The Dalles Dam has passed large numbers of surface-oriented juvenile migrants in a small amount of water compared to spill over the spillways (Whitney et al. 1997; Figure 3). The surface overflow at the downstream end of the powerhouse was designed to collect woody debris and surface ice that had been drawn to the powerhouse by the turbine-induced currents. It also serves that purpose for surface-oriented juvenile salmon drawn to the powerhouse that become stalled in their migration by failure to immediately enter the deep turbine entrances. This structure has given impetus for much research and development on surface bypasses.

\subsection{Wells Dam Hydrocombine}

Another dam development fortuitously demonstrated the importance of surface bypasses for passing juvenile migrants. Wells Dam was constructed with a "hydrocombine" design in which the spillway and powerhouse are one structure. Water is spilled above the turbines from the water that overlies the turbine intake. Downstream migrants drawn to the powerhouse near the surface are less apt to be stalled, and they pass over the spillway largely unimpeded. Wells Dam tends to pass about $90 \%$ of the migrants in less than $10 \%$ of the river flow, thus allowing the remainder to be used for power generation (Skalski et al. 1996; Coutant and Whitney 2000). The Wells configuration was been emulated for testing of add-on surface bypass structures at Bonneville Dam and elsewhere.

\subsection{Improvements in Surface Bypasses}

Development of surface bypasses for more ecologically normative, less hazardous, and waterefficient juvenile fish passage was spurred by recommendations and requirements of advisory and regulatory bodies through the mid and late 1990s. The Independent Scientific Advisory Board (ISAB) and the Independent Scientific Review Panel (ISRP) reviewed surface bypass studies and recommended accelerated development. The Northwest Power Planning Council (now called the Northwest Power and Conservation Council) included mandates for surface bypass development in its 1995 Columbia River Basin Fish and Wildlife Program. The 2000 Biological Opinion by NOAA Fisheries (National Marine Fisheries Service) on the operation of the FCRPS under the Endangered 
Species Act included several actions for surface bypass development in the Reasonable and Prudent Alternative.

\subsubsection{Surface Bypass at Rocky Reach Dam}

The Chelan County Public Utility District has, for several years, conducted research and development on surface bypass technologies at its Rocky Reach dam (Johnson et al. 1997; Peven and Mosey 1998). This dam is constructed in a shape that funnels surface-migrating juvenile salmon towards a cul-de-sac in the turbine forebay. Despite spill over the spillways (spill being the standard approach for non-federal, FERC-licensed projects on the Columbia River), many fish became entrapped near the surface in the cul-de-sac, were delayed in their migration, and eventually passed through the turbines where damages occurred. Some means of collecting these fish from the forebay and guiding them to a safe passage route has been the continuing objective of Chelan County PUD. After testing several prototypes, a final design was implemented in 2003. Use of the bypass reduces the need to spill water over the dam. That unspilled water is used to generate electricity which more than offsets the $\$ 112$ million cost of the bypass. Over 15 years, the bypass is expected to save spill worth about \$400 million. (Steig et al. 2001; Chelan PUD 2003; http://www.chelanpud/hydro/rr/Rocky.htm)

\subsubsection{Surface Bypasses at Corps Dams}

Several surface bypass designs have been investigated at Columbia River dams operated by the Corps of Engineers (Johnson et al. 1997; Dauble et al. 1999). Bulkheads with near-surface releases were installed just upstream of Tainter gates at The Dalles Dam, various sizes and shapes of vertical slots as well as a surface skim design were tested at sluices at Ice Harbor Dam, channels over the powerhouse were tested at Bonneville and Lower Granite dams. Lower Granite Dam became the main location for testing surface bypass prototypes. Effectiveness was mixed, but understanding of both biology and engineering grew. Performance of both the surface bypass itself and the guidance of fish toward it were understood to be important.

\subsubsection{Wanapum Dam Surface Bypass Prototype}

A prototype powerhouse channel surface bypass was also developed at the non-federal Wanapum Dam, where spill has been the main fish passage route provided, to the detriment of generating capability. The channel hung over the powerhouse entrances, with the intent of collecting surfaceoriented juveniles. Concurrent operation of spillways provided little opportunity for fish to discover the surface bypass, and performance was poor (Kumagai et al. 1997). As in the Corps' studies, attraction to the bypass in the dam forebay is key to success. A modified bypass is expected to be installed by 2007 in place of a future turbine Unit 11.

\subsubsection{Bonneville Corner Collector}

The Second Powerhouse at Bonneville Dam has been a source of consternation over juvenile fish passage. The entire production of the Columbia River Basin must pass Bonneville Dam, so high mortalities at this point are especially unacceptable. Despite its relatively recent construction, the Second Powerhouse has had a particularly ineffective fish screening and bypass system. Nonetheless, an ice and trash sluiceway built at the south end of the powerhouse seemed to effectively pass large numbers of juvenile migrants (Figure 9). Its performance seemed to mimic the high fish-passage efficiency of the ice and trash sluiceway at The Dalles Dam, discussed above. Attraction to the location of the sluice was occurring without special guidance devices. It was clear that fish were 
drawn hydraulically toward the powerhouse and, similar to Rocky Reach, they became concentrated in the "corner" formed by the powerhouse and the adjoining abutment. Exit by way of the sluice was both biologically and hydraulically logical in contrast to having fish dive to the depths of the turbine intakes. Therefore, the sluiceway was modified to become a full-fledged fish bypass system, principally by extending the sluiceway farther down the island that separates the powerhouse from the spillway (USACE 1997).

\subsubsection{Removable Spillway Weir}

The Corps of Engineers responded to calls for an improved surface bypass by developing a Removable Spillway Weir (RSW). This is a surface overflow weir installed as an insert into a standard spillway gate nearest the powerhouse. The weir replaces the function of the existing Tainter gate (which withdraws water from as deep as 50 feet) with a surface overflow similar to an ice and trash sluiceway or the successful surface-flow spillways tested earlier using modified stop logs. Because spillways at each dam are designed for the record floods, there is a potential need to have full functionality of the spillway gate used. Therefore, the weir was designed as a self-contained structure that could be tilted into the dam forebay and made completely free of the spillway opening (Figures 7 and 8).

A prototype RSW was installed at Lower Granite Dam in summer 2001 and tested for its fish-passage efficiency in springs of 2002 and 2003. In 2002, the tests showed that the RSW was an effective route of passage for fish, discharging $8.5 \%$ of the water through the dam yet passing 56-62\% of the tagged fish over the course of the study (Anglea et al. 2003; Plumb et al. 2003). Further tests in 2003 when conditions were established more similar to other dams (other test structures were removed), showed that the RSW hastened movement through the dam's forebay compared to normal maximum spill (delay reduced by half) and fewer fish moved back upstream when encountering the dam (one third as many hatchery Chinook salmon and half as many hatchery steelhead moved upstream as in normal spill) (Plumb et al. 2004). Survival was also better through the RSW than through conventional spill $(98.0 \% \pm 2.3$ for RSW, $93.1 \pm 6.0$ for spill).

\subsubsection{Summary of Alternatives}

Although there are alternatives to spill, either in place or under development, spill still continues as the main "technology" for fish passage in the mainstem Columbia and Snake rivers other than collection and transportation. This is true for the federal and non-federal dams. Part of the reason for its prominence is that, as noted in the introduction, spill seems most "natural" and as such is supported by certain stakeholders. Also, implementation of alternative technologies takes time for development, testing, and installation and thus is not immediately available, as is spill. Another part of the equation is cost. Simply installing a known technology like the Corner Collector or the RSW at every dam is something that annual budgets seem not to allow. This report explores the cost aspect in a later section. 


\section{THE 2004 FCRPS SPILL CONTROVERSY}

With the economics of managed spill for fish migration so unfavorable for a region whose water resources are over subscribed and whose hydropower needs are great, it is instructive to review in detail the attempts by management agencies to limit managed spill for fish passage in order to boost hydropower production. One's perspective of the controversy that arose is informed by the brief background on other available bypass technologies presented above, especially surface bypasses.

In early 2004, the Bonneville Power Administration (BPA) and the U.S. Army Corps of Engineers together, (the Action Agencies) proposed to change managed spill in the Federal Columbia River Power System (FCRPS) for three years (2004 to 2006; BPA and the Corps 2004a). In exchange for this change, they would provide fish mitigation in the form of "offsets" (Preliminary Proposal, released March 30, 2004). The fish primarily affected would be the summer-migrating fall Chinook salmon, including the ESA-listed Snake River stock. Under this proposal, August managed spill at Ice Harbor, John Day, The Dalles, and Bonneville dams would have ceased. In July, managed spill would have been modified from the levels mandated in the 2000 NMFS' Biological Opinion according to the dam: Ice Harbor Dam would have ceased spilling on July 15 while Bonneville spill would be reduced from 75 to $50 \mathrm{kcfs}$. This proposal received numerous critical comments from the resource agencies and environmental groups.

An Amended Proposal was released by the Action Agencies on June 8 that would have initiated only a one-year reduction in summer spill operations and provided mitigation using offsets. The proposal again consisted of specific spill management at specific dams. Clearly, the Action Agencies intended that after this first year some spill reduction would continue in future years. Additional offsets for summer spill reductions in 2005 and 2006 were offered for discussion. The proposal was modified again in late June. An amendment to the 2004/2004-2008 Implementation Plan for the FCRPS Biological Opinion Remand (the Revised BiOp), released June 23, 2004, made relatively small changes to the Amended Proposal.

For each stage of the Action Agencies' proposal, offsets were proposed to mitigate for estimated fish losses from reducing spill. The offsets consisted of short-term actions to compensate with increased fish abundance or better survival for the fish losses from curtailed spill. It is significant that these were short-term actions. The agencies' quantitative estimates of fish losses were matched by estimated benefits from the offsets.

The offsets proposed were:

(1) Augmentation of the northern pikeminnow management program, to include focused removals of this predatory fish from Bonneville, The Dalles, and John Day dam forebays and tailrace boat restricted zones as well as a general increase in the reward structure in the Sport-Reward Fishery to provide systemwide enhancement and benefit to all affected salmon stocks that might be eaten by this fish, and

(2) Operational management to reduce stranding of fall Chinook salmon in the Hanford Reach that would obligate BPA through a long-term agreement to maintain certain outflows from the federal projects upstream of Priest Rapids Dam so that Priest Rapids could provide adequate, sustained flows to the Hanford Reach immediately downstream. BPA would deliver Grant PUD amounts of energy to mitigate generation losses that Grant would incur from operating Priest Rapids to limit hourly and daily flow fluctuations. 
The total change in survival to adults from reduced summer spill and offsets was estimated by the Action Agencies. Their analysis suggested that the two offsets would not entirely compensate for losses. Losses to non-listed Hanford Reach fall Chinook would be fully compensated by Hanford Reach anti-stranding measures, but the ESA-listed Snake River fall Chinook would not, and the pikeminnow reduction might not increase survival of other non-listed Chinook enough to compensate for spill reductions.

Therefore, other actions were "also under consideration as possible offsets." These were

- Council Fish and Wildlife Program enhancement (exact actions not specified)

- Additional flow augmentation from Dworshak Reservoir

- Tribal harvest enforcement funding

- Additional or improved artificial production

- Avian predation research

- Additional water acquisitions

- Habitat protection/enhancement

- Commercial harvest reductions (non-tribal), as available

- Additional Removable Spillway Weirs

No offset funding would have gone to other fish bypass research and development, seen by many as the only long-term alternative to managed spill for fish passage. Only the Corps' Removable Spillway Weir was considered, and then only in a very vague way.

The Amended Proposal provided an expanded set of offsets, as well as additional modeling and analysis relative to that in the Preliminary Proposal. The intent of the Action Agencies was to fully offset the impacts of the proposed 2004 spill-reduction operation on ESA-listed fish. The largest offset, and the only one included in the Revised BiOp, was an additional volume of water $(100,000$ acre-feet in July) provided from storage in Idaho Power Company's (IPC) Brownlee Reservoir on the Snake River to benefit outmigration of Snake River fall Chinook subyearlings with added flow (assumed to increase migration velocity). The cost to BPA would have been \$4 million. In retrospect, this offer might have been counterproductive biologically, for the water would have been warmer than existing Snake River water and thus harmful to juvenile salmon from high-temperature effects.

Estimated increases in power revenue and costs of offsets for the Preliminary and Amended Proposals were provided by the Action Agencies. For the Preliminary Proposal, gross power revenues would be increased by an average of $\$ 47$ million per year, or $\$ 141$ million over three years. After deducting the incremental costs of offsets, the Preliminary Proposal was expected to provide net revenue of about $\$ 120$ million, or $\$ 40$ million per year, over three years. This net revenue included additional expenditure of \$10 million for the fish and wildlife program over 3 years, plus $\$ 6$ to $\$ 15$ million of other, unspecified offsets. The amended proposal would have grossed \$33-44 million per year, with a net after offsets of \$20-31 million. None of these specific offset costs included alternative bypass research, development, or deployment.

Significantly, the Action Agencies included installation of Removable Spillway Weirs (RSWs) and development of bypass technologies in the list of options for 2005-2006, although only vaguely and without costs. The RSW was not included in the 2004 offsets because of the long time required for RSW installation and the short time available between the proposals (spring 2004) and the intended implementation of spill reduction (summer 2004). Based on evaluations of the RSW performance at Lower Granite Dam, a long-term effort to accelerate installation of RSWs and other bypass technologies would allow spill reductions without adverse effects on fish passage. The resource agencies were supportive of this direction. The Washington Department of Fish and Wildlife recommended expedited installation of RSWs or other surface bypass at McNary and Little Goose 
dams, followed by John Day and Lower Monumental dams, and The Dalles Dam. The Action Agencies agreed that surface bypass methods have the potential to provide for lower spill volumes than the current operation, with similar or better project survival. The Action Agencies were on an expedited schedule to install an RSW at Ice Harbor Dam on the Snake River in winter 2004-2005 with initial testing conducted in spring 2005. The Dalles Dam is a high priority in the lower river, where the Action Agencies have been planning to install a forebay juvenile guidance device. The next Snake River priority identified is Lower Monumental Dam.

There was much controversy over the proposals by the Action Agencies, including lawsuits, and in the end none was accepted for implementation in 2004. Tribal interests, environmental groups, and fisheries agencies raised many issues with the analyses used by BPA and the Corps to support the Preliminary Proposal. Particularly contentious were the Action Agencies' calculations of reduced juvenile fish survival with reduced spill and increased survival from the offsets. An exceptional amount of controversy was associated with juvenile survival and smolt-to-adult returns in the Snake River system, where ESA-listed stocks predominate. Tribal analyses indicated negative effects on ESA-listed adults 10-15 times as large as estimated by the Action Agencies' analysis. Similarly different results were obtained by the Fish Passage Center. Despite additional offsets in the Amended Proposal, the resource agencies did not agree that an acceptable balance had been achieved. Uncertainty in fish estimates reduced confidence in the cost effectiveness of the proposal. There was much less debate over changes in power production and revenue savings from managed spill reductions and the costs of offsets.

In our opinion, the enduring conclusion from this high-intensity attempt to reduce spill in the FCRPS in 2004 is not the one reached (no implementation). It is the pressing need for rigorous research, development, and demonstration with juvenile fish bypasses that are ecologically normative and installation of technologies that appear successful such as the RSW and the "corner collector" at Bonneville's Second Powerhouse. To do so, cost is the logical concern. 


\section{IEAB COST-EFFECTIVENESS ANALYSIS}

Despite uncertainties about biological estimates of changes in survival of juvenile salmon from spill reduction or compensatory mitigation (offsets), there is an opportunity to compare less contentious estimates for power production, revenue savings from spill reduction, and the costs of a variety of potential compensatory or mitigation strategies to increase smolt survival. Such an analysis is particularly opportune when it focuses on long-term approaches for simultaneously improving fish survival, increasing electricity production, and creating a net economic benefit for society. Such was a preliminary analysis conducted by the Independent Economic Analysis Board (IEAB or Board) of the Northwest Power and Conservation Council (Council)(IEAB 2004).

The IEAB (2004) presents principles and examples of the application of cost-effectiveness analysis (CEA) to actions intended to improve mainstem passage survival in the Snake River basin while reducing spill and increasing power generation. The board reviewed CEA principles and discussed related analyses and policy issues. The Board developed examples of applying CEA to managed (bypass) spill and bypass facility modifications using information from a hydrosystem model (Genesys, operated by the Northwest Power and Conservation Council), a model of Western power pricing (AURORA TM, licensed by the Council from EPIS, Inc.), a model of juvenile salmon and steelhead survival (SIMPAS, developed by the National Marine Fisheries Service), and information on actual costs of bypass facility modifications already constructed in the basin.

Although preliminary, the IEAB's CEA analysis predicted that juvenile passage survival can be increased in the long run at a net cost reduction to power consumers. This is accomplished by reducing spill, generating electricity with the water saved, using enhanced revenues along with the ability to borrow against future power revenues, and applying the funds to the development and deployment of fish-passage technologies. The result would be to speed the implementation of passage improvements and ultimately the recovery of listed species and other salmon populations.

The Board developed simple cost-effectiveness measures for actions that have measurable survival and cost benefits. There is a history of developing fish-passage technologies, discussed above, for which both costs and survival benefits have been determined or estimated. These technologies include extended-length screens for turbine intake bypasses at Lower Granite and Little Goose dams, and the Corner Collector at Bonneville Dam's second powerhouse. The measure chosen for the examples is the cost of the fish-passage improvement divided by the change in the percent of juvenile migrants surviving through the mainstem to below Bonneville Dam (that is, the cost per unit increase in juvenile survival). These measures are compared to the revenue per unit increase in juvenile survival from spill reductions, particularly eliminating managed August spill at Ice Harbor Dam.

The Board's analysis suggested that extended length screens at Lower Granite and Little Goose dams and the Bonneville second powerhouse Corner Collector are highly cost effective (Table 2). For example, the extended-length screens at Lower Granite Dam appear to be approximately 50 times (600/12) more cost effective for fall Chinook salmon juvenile passage than August spill at Ice Harbor. The cost effectiveness of the Bonneville Corner Collector appears to be approximately 6 times (600/95) more effective than the August spill at Ice Harbor. 
Table 2. Summary of cost per unit of juvenile survival for selected passage actions in the juvenile cost-effectiveness analysis. From IEAB 2004.

\begin{tabular}{lccc}
\hline & \multicolumn{3}{c}{$\begin{array}{c}\text { Million per year per percentage point } \\
\text { increase in juvenile survival }\end{array}$} \\
\cline { 2 - 4 } & Fall Chinook & $\begin{array}{c}\text { Spring/summer } \\
\text { Chinook }\end{array}$ & Steelhead \\
\hline $\begin{array}{l}\text { August spill at Ice Harbor Dam } \\
\begin{array}{l}\text { Extended-length screens at Lower } \\
\text { Granite Dam }\end{array}\end{array}$ & $\$ 600$ & No effect & No effect \\
$\begin{array}{l}\text { Extended-length screens at Little } \\
\text { Goose Dam }\end{array}$ & $\$ 12$ & $\$ 3$ & $\$ 6$ \\
$\begin{array}{l}\text { Corner Collector at Bonneville } \\
\text { Dam }\end{array}$ & $\$ 23$ & $\$ 7$ & $\$ 14$ \\
\hline
\end{tabular}

The analysis also considered the RSW planned for Ice Harbor Dam, and RSWs proposed for Little Goose and Lower Monumental dams. RSWs are treated somewhat differently in the Board analysis because they are assumed to have no direct effect on survival. Instead, increased revenues from reduced spill can be compared directly to their costs, and net revenues can be used to fund other passage improvements that do increase survival.

The analysis pointed out potential investments in fish passage improvements that may not be cost effective and should be put on hold pending an improved cost-effectiveness showing. For example, installing a RSW at Little Goose Dam does not appear to be cost effective, for increased power revenues with current system operation would not be enough to pay for the weir system. Results at Lower Monumental Dam were equivocal. These RSWs might be cost effective if their survival benefit is increased or if costs are reduced (such as not needing a behavioral guidance system in the dam forebay in addition to the weir itself).

The Board's analysis also showed how CEA could be used to identify combinations of actions, or scenarios, that make both power consumers and fish better off. In these analyses, a small percentage increase in fish survival is accepted while showing a net economic benefit (in reality, a greater increase in fish survival could be provided with a concomitant lower net economic benefit). For these analyses, capital costs of facilities are annualized over 20 years at 4 percent real interest. The Board summarized three such scenarios (Table 3).

The first scenario combines the cessation of August managed spill at Ice Harbor with installation of extended-length screens at Lower Granite and Little Goose dams. Increased power revenues from reduced spill were estimated to be greater than the annualized costs of the extended-length screens, so net power system revenue (increased power revenues net of passage improvement costs) of \$900,000 would be returned to ratepayers annually. At the same time, survival of Snake River juveniles would be expected to increase by $0.31 \%$ to $1.11 \%$, depending on the stock. In other words, power revenues from eliminating managed spill in August at just one Snake River dam (Ice Harbor) could have funded the cost of major improvements in fish passage at two other dams (Lower Granite and Little Goose) increasing smolt survival and yielding a net power system revenue of nearly one million dollars each year. 
A Removable Spillway Weir at Ice Harbor Dam appears to be cost effective in combination with reducing annual managed spill at that dam by half (the RSW itself needs to spill some water to function) but not affecting smolt survival. Increased power revenues from reduced spill would be more than enough to finance the weir. In fact, the revenues would be sufficient to pay for Ice Harbor's RSW and build the Bonneville Corner Collector, while yielding $0.03 \%$ to $0.05 \%$ increase in fish survival, depending on stock (essentially maintaining no loss), and providing a \$6.26 million annual benefit for the consumer.

The Board acknowledged certain limitations to its preliminary CEA study. First, the costs of some facilities are retrospective (reflect costs of facilities already built) and might be higher under future costing. The recent actual costs were, however, believed to be more reliable than future estimates. When costs were uncertain, the higher of a range was selected. Second, the effects of passage improvements on smolt survival are somewhat uncertain, as the intense debate in 2004 over implementing spill reductions demonstrated. The analysis was based on conservative assumptions regarding biological benefits, however. The analysis was based simplistically on annual average river flow conditions, whereas results in any given year with different flows might be different for both costs and effectiveness. Nonetheless, the general principles seem well demonstrated.

A major limitation for the federal power system is that there is currently no direct institutional mechanism whereby power revenues from reduced managed spill can be used to fund fish passage improvements. Although BPA and the basin's Implementation Team, made up of representatives from federal and state agencies, the tribes, and utilities, have some discretion for funding passage improvements, a basic change in funding mechanisms is likely needed. The non-federal hydropower producers already have this flexibility.

The Board's analysis did not directly address research and development of new fish-passage technologies, but the same principle of investing revenues from spill reduction would apply. For instance, experimental modifications of the ice and trash sluiceway at The Dalles Dam could be funded. A limitation of prototype surface bypasses at Lower Granite and Bonneville dams has been lack of an effective attraction flow to guide smolts to the entrance, which could be remedied by research on turbulent attraction flows (Coutant 2001a). The outfalls of present turbine-intake bypasses are in need of study and modification to reduce predation on disoriented smolts. Multisensory behavioral technologies involving selective repulsion and attraction using flows, strobe lights, and sounds may be effective in aiding smolt guidance and passage (Coutant 2001b). The current dearth of information on smolt passage through reservoirs, where delays and predation are strong influences on survival (ISAB 2003), could be alleviated by funds from more cost-effective spill management. These are but examples. Research and development, in combination with capital investment in installations, could benefit from the sort of cost-effectiveness analyses and innovative financing suggested by the IEAB. 


\section{CONCLUSIONS}

Although spill is currently the preferred option for moving juvenile salmon downstream, reducing managed spill and increasing generation could:

(1) pay for installing known fish-passage improvements such as Removable Spillway Weirs and Corner Collectors (or other surface bypasses) at other dams;

(2) pay for extended-length screens where they do not exist;

(3) probably pay for replacement of old turbines with more fish-friendly designs (not explicitly studied);

(4) pay for research and development of new surface bypass technologies; and

(5) pay for research on assisting smolt migrations through reservoirs (although these last three have not been analyzed economically).

The outcomes would be more rapid deployment of fish-passage technologies, long-term improvement in smolt survival through the hydrosystem, increased generation of electricity thereby fostering use of renewable energy, and net revenue benefit for society.

These results would require development of institutional mechanisms whereby power revenues from reduced managed spill could be used to fund passage improvements. 


\section{REFERENCES}

Absolon, R.F., E.M. Dawley, B.P. Sanford, J.W. Ferguson, and D.A. Brege. 2000. Relative survival of juvenile salmonids passing through the spillway of TDA, 1997-2000. Draft Report to U.S. Army Corps of Engineers, Portland District, Portland, OR. Contract W66QKZ83437725.

Anglea, S.M., K.D. Ham, G.E. Johnson, M.A. Simmons, C.S. Simmons, E. Kudera, and J. Skalski. 2003. Hydroacoustic evaluation of the removable spillway weir at Lower Granite Dam in 2002. Annual report to the U. S. Army Corps of Engineers, Contract DACW68-02-C-0001, Walla Walla, Washington.

Beeman, J.W., H.C. Hansel, P.V. Haner, K. Daniel, and J.M. Hardiman. 2003. Estimates of fish and spill passage efficiency of radio-tagged juvenile steelhead, and yearling and subyearling Chinook salmon at John Day Dam, 2000. Prepared by the U.S. Geological Survey for the U.S. Army Corps of Engineers, Portland, Oregon.

Bell, M.C., and A.C. DeLacy. 1972. A compendium on the survival of fish passing through spillways and conduits. Report to the Portland District U.S. Army Corps of Engineers, Portland, OR.

Bonneville Power Administration and U.S. Army Corps of Engineers. 2004a. Preliminary Proposal for FCRPS Summer Juvenile Bypass Spill Operations. March 30.

BPA and USACE. 2004b. Amended Proposal for FCRPS Summer Juvenile Bypass Operations. June 8.

BPA and USACE. 2004c Amendment to the 2004/2004-2008 Implementation Plan for the FCRPS Biological Opinion Remand. June.

BPA and USACE. 2004b. Amended Proposal for FCRPS Summer Juvenile Bypass Operations. Appendix A. Additional Information on the Updated Impacts Analysis For the Proposed Summer Spill Reductions.

Brege, D.A., J.W. Ferguson, R.F. Absolon, and B.P. Sandford. 2000. Studies to evaluate the effectiveness of extended-length screens at John Day Dam, 1999. Report to U.S. Army Corps of Engineers by National Marine Fisheries Service, Northwest Fisheries Science Center, Seattle, Washington.

Brown, S., and G. Garnant. 2006. Advanced-design turbine at Wanapum Dam improves power output, helps fish. HydroReview XXV(2): SR2-SR7.

Cada, G.F., C.C. Coutant, and R.R. Whitney. 1997. Development of biological criteria for the design of advanced hydropower turbines. U.S. Department of Energy Report DOE/ID-10578, Idaho Falls, Idaho.

Cada, G.F., T.J. Carlson, D.D. Dauble, R.T. Hunt, M.J. Sale, and G. L. Sommers. 2004. DOE Hydropower Program Annual Report for FY 2003. DOE/ID-11136, U. S. Department of Energy, Office of Energy Efficiency and Renewable Energy, Wind and Hydropower Technologies, Washington, DC. 
Carlson, T.J. and J.P. Duncan. 2003. Evolution of the sensor fish device for measuring physical conditions in severe hydraulic environments. Report to the U.S. Department of Energy, Idaho Operations Office. Idaho Falls ID. Report DOE/ID-11079.

Chelan PUD (Public Utility District No. 1 of Chelan County). 2003. Rocky Reach and Rock Island fish passage plans. Wenatchee Washington.

Cooper, S. 2003 summer spill - two week curtailment option. Bonneville Power Administration, Portland, Oregon.

Coutant, C.C. 2001a.Turbulent attraction flows for guiding juvenile salmonids at dams. American Fisheries Society Symposium 26:57-77.

Coutant, C.C. 2001b. Integrated, multi-sensory, behavioral guidance systems for fish diversions. American Fisheries Society Symposium 26:105-113.

Coutant, C.C., and R.R. Whitney. 2000. Fish behavior in relation to passage through hydropower turbines: a review. Transactions of the American Fisheries Society 129: 351-380.

Dauble, D.D., S.M. Anglea, and G.E. Johnson. 1999. Surface flow bypass development in the Columbia and Snake rivers and implications related to research at Lower Granite Dam. U. S. Army Corps of Engineers, Walla Walla District, Walla Walla, Washington.

CRSOR (Columbia River System Operation Review, a joint project of the U.S. Bureau of Reclamation, U.S. Army corps of Engineers, and Bonneville Power Administration). 1991. The Columbia River system: the inside story. Portland, Oregon.

Giorgi, A.E., M. Miller, and J. Stevenson. 2002. Mainstem passage strategies in the Columbia River systems: transportation, spill, and flow augmentation. Prepared by Bioanalysts, Inc. for the Northwest Power Planning Council, Portland, Oregon.

Hansel, H.C., N.S. Adams, T.D. Counihan, B.D. Liedtke, M.S. Novick, J.M. Plumb and T.P. Poe. 1999. Estimates of fish and spill passage efficiency for radio-tagged juvenile steelhead and yearling Chinook salmon at John Day Dam, 1999. Annual report of research to U. S. Army Corps of Engineers, Portland, District, Portland, OR.

Hansel, H.C., J. W. Beeman, B.J. Hausmann, S.D. Juhnke, P.V. Haner, and J.L. Phelps. 2003. Estimates of fish-, spill-, and bypass-passage efficiency of radio-tagged juvenile salmonids relative to spring and summer spill treatments at John Day Dam in 2003. Preliminary report to the U.S. Army Corps of Engineers, Portland, Oregon, October 9, 2003.

IEAB (Independent Economic Analysis Board). 2004. Juvenile Passage Cost Effectiveness Analysis for the Columbia River Basin: Description and Preliminary Analysis. IEAB 2004-01, Northwest Power and Conservation Council, Portland, Oregon.

ISAB (Independent Scientific Advisory Board). 2003. Review of flow augmentation; Update and clarification. Report ISAB 2003-1. Northwest Power and Conservation Council, Portland, Oregon. 
Iwamato, R.N., Muir, W.D., Sandford, McIntyre, Frost, D.A., Williams, J.G., Smith, S.G., and J.R. Skalski. 1994. Survival estimates for the passage of juvenile Chinook salmon through Snake River Dams and reservoirs, 1993. Report prepared for the U.S. Department of Energy, Bonneville Power Administration. Division of Fish and Wildlife, Contract DE-A179-93BP10891, Project 93-29. 139 pp.

Johnson, G.E., A.E. Giorgi, and M.W. Erho, Jr. 1997. Critical assessment of surface flow bypass development in the Lower Columbia and Snake rivers. Prepared for U. S. Army Corps of Engineers, Portland District, Portland, Oregon and Walla Walla District, Walla Walla, Washington.

JTS (State, Federal, and Tribal Fishery Agencies Joint Technical Staff). 2004. Comments on Action Agencies’ Preliminary Proposal, April 7.

Kumagai, K.K., B.H. Ransom, H.A. Sloan and H. Charvet. 1997. Effectiveness of a prototype surface flow attraction channel for passing juvenile salmon and steelhead trout at Wanapum Dam during spring 1997. Final report to Grant County PUD, Wenatchee, Washington.

Mighetto, L., and W.J. Ebel. 1994. Saving the salmon: A history of the U.S. Army Corps of Engineers' efforts to protect anadromous fish on the Columbia and Snake rivers. Report for the U.S. Army Corps of Engineers, North Pacific Division, Portland and WallaWalla Districts. Historical Research Associates, Inc., Seattle, Washington.

Muir, W.D., S.G. Smith, J.G. Williams, and B.P. Sandford. 2001. Survival of juvenile salmonids passing through bypass systems, turbines, and spillways with and without flow deflectors at Snake River dams. North American Journal of Fisheries Management 21:135-146.

Normandeau Associates, J.R. Skalski, and Mid Columbia Consulting, Inc. 2003. Estimated direct mortality and injury of juvenile salmonids in passage through The Dalles spillway, Columbia River in spring and summer 2002. Report prepared for U.S. Army Corps of Engineers, Portland District, Portland, Oregon.

Normandeau Associates, Inc., J.R. Skalski, and R.L. Townsend. 2006. Performance evaluation of the new advanced hydro turbine system at Wanapum Dam, Columbia River, Washington. Final report to Public Utility District No. 2 of Grant County, Ephrata, Washington.

NPCC (Northwest Power and Conservation Council). 2003a. Cost and energy impacts of fish and wildlife operations. May 9, 2003. Portland, Oregon.

NPCC (Northwest Power and Conservation Council). 2003b. Fish and energy impacts resulting from reductions in summer bypass spill. July 16. Portland, Oregon.

NPCC (Northwest Power and Conservation Council). 2003c. Mainstem Amendments to the Columbia River Basin Fish and Wildlife Program. NPCC Document 2003-11.

NPCC (Northwest Power and Conservation Council). 2005. Fifth Power Plan (prepublication version). Appendix O. The interaction between power planning and Fish and Wildlife Program development. Report No. 2004-18. Portland, Oregon.

NPPC (Northwest Power and Planning Council). 1994. Columbia River Basin Fish and Wildlife Program. Report 94-55. Portland, Oregon. 
NPPC (Northwest Power and Planning Council). 1999. Report and recommendations of the Northwest Power Planning Council upon review of the Corps of Engineers' Columbia River Fish Mitigation Program. Report to Congress. Council Report 99-5, Portland, Oregon.

NPPC (Northwest Power and Planning Council). 2001. Effects of 2001 Mid-Columbia hydropower operations on fish: Addendum to the Federal Columbia River Power System issue paper (Council Document 2001-9). Portland, Oregon.

Peven, C.M., and T.R. Mosey. 1998. Biological and hydraulic evaluation of the Rocky Reach surface collector - 1997. Chelan County Public Utility District, Wenatchee, Washington.

Ploskey, G., T. Poe, A. Giorgi, and G. Johnson. 2001. Synthesis of hydroacoustic, radio telemetry, and survival studies of juvenile salmon at The Dalles Dam (1982-2000). Technical report to the U. S. Army Corps of Engineers, Portland, Oregon.

Plumb, J.M., A.C. Braatz, J.N. Lucchesi, S.D. Fielding, J.M. Spando, G.T. George, N. S. Adams, and D. W. Rondorf. 2003. Behavior of radio-tagged juvenile Chinook salmon and steelhead and performance of a removable spillway weir at Lower Granite Dam, Washington, 2002. 2002 Final report by the U. S. Army Corps of Engineers, Contract number W68SBV00104592, Walla Walla, Washington.

Plumb, J.M., A.C. Braatz, J.N. Lucchesi, S.D. Fielding, A.D. Cochran, T.K. Nation, J.M. Sprando, J.L. Schei, R.W. Perry, N.S. Adams, and D.W. Rondorf. 2004. Behavior and survival of radio-tagged juvenile Chinook salmon and steelhead relative to the performance of a removable spillway weir at Lower Granite Dam, Washington. 2003 Final report by the U. S. Army Corps of Engineers, Contract number W68SBV00104592, Walla Walla, Washington.

Ruggles, C.P., and D.G. Murray. 1983. A review of fish response to spillways. Canadian Technical Report of Fisheries and Aquatic Sciences.

Sale, M.J., G.F. Cada, T.L. Acker, T. Carlson, D.D. Dauble, and D.G. Hall. DOE Hydropower Program Biennial Report for 2005-2006. ORNL/TM-2006/97. Oak Ridge National Laboratory, Oak Ridge, TN. 59 p.

Schoeneman, D.E., R.T. Pressey, and C.O. Junge, Jr. 1961. Mortalities of downstream migrant salmon at McNary Dam. Transactions of the American Fisheries Society 117:196-201.

Shively, R.S., T.P. Poe, and M.B. Sheer. 1996. Criteria for reducing predation by northern squawfish near juvenile salmonid bypass outfalls at Columbia River dams. Regulated Rivers Research and Management 12:493-500.

Skalski, J.R., G.E. Johnson, C.M. Sullivan, E.A. Kudera, and M.W. Erho. 1996. Statistical evaluation of turbine bypass efficiency at Wells Dam on the Columbia River, Washington. Can. J. Fish. Aquat. Sci. 53:2188-2198.

Snelling, J.C., and C.B. Schreck. 1994. Movement, distribution, and behavior of juvenile salmonids passing through Columbia and Snake River Dams. Bonneville Power Administration. Project 82003. Portland, Oregon. 
Steig, T.W., B.H. Ransom, and M.A. Timko. 2001. Monitoring the behavior of acoustically tagged Chinook and steelhead smolts approaching Rocky Reach Dam on the Columbia River. Waterpower XII. HCI Publications, Inc. Kansas City, Missouri.

Sommers, G.L., and 7 co-authors. 2005. DOE Hydropower Program Annual Report for FY 2004. U.S. Department of Energy, Idaho Operations Office, Idaho Falls, Idaho.

USACE (U.S. Army Corps of Engineers). 1997. Bonneville Second Powerhouse Prototype Corner Collector. Prepared by INCA Engineers and associates. Portland District, Portland, Oregon.

USACE (U. S. Army Corps of Engineers). 2004. Turbine Survival Program. Phase I Report 19972003. Portland District, Portland, Oregon and Walla Walla District, Walla Walla, Washington.

Washington Department of Fish and Wildlife. 2004. Proposed package to offset effects of potential reduction of summer spill at several Columbia River federal dams. March 29.

Whitney, R.R., L.D. Calvin, M.W. Erho, Jr., and C.C. Coutant. 1997. Downstream passage for salmon at hydroelectric projects in the Columbia River basin: development, installation, and evaluation. Report 97-15. Northwest Power Planning Council, Portland, Oregon.

Williams, J.G., S.G. Smith, and W.D. Muir. 2001. Survival estimates for downstream migrant yearling juvenile salmonids through the Snake and Columbia rivers hydropower system, 1966-1980 and 1993-1999. North American Journal of Fisheries Management 21: 310-317. 
ORNL/TM-2005/179

\section{INTERNAL DISTRIBUTION}

1. M. S. Bevelhimer

2. G. F. Cada

3-7. C. C. Coutant

8. R.A. Hawsey

9. G. K. Jacobs
10-14. M. J. Sale

15. B. T. Smith

16-17. ESD Library

18. ORNL Central Research Library

19. ORNL Laboratory Records RC

\section{EXTERNAL DISTRIBUTION}

20. Jim Ahlgrimm, EE-2B, US Department of Energy, Office of Wind \& Hydropower Technologies, Room 5H/072 FORS, 1000 Independence Ave., SW, Washington DC 20585 



\section{A Strong Energy Portfolio for a Strong America}

Energy efficiency and clean, renewable energy will mean a stronger economy, a cleaner environment, and greater energy independence for America. By investing in technology breakthroughs today, our nation can look forward to a more resilient economy and secure future.

Far-reaching technology changes will be essential to America's energy future. Working with a wide array of state, community, industry, and university partners, the U.S. Department of Energy's Office of Energy Efficiency and Renewable Energy invests in a portfolio of energy technologies that will:

- Conserve energy in the residential, commercial, industrial, government, and transportation sectors

- Increase and diversify energy supply, with a focus on renewable domestic sources

- Upgrade our national energy infrastructure

- Facilitate the emergence of hydrogen technologies as vital new "energy carriers."

\section{The Opportunities}

\section{Biomass Program}

Using domestic, plant-derived resources to meet our fuel, power, and chemical needs

Building Technologies Program

Homes, schools, and businesses that use less energy, cost less to operate, and ultimately, generate as much power as they use

Distributed Energy \& Electric Reliability Program

A more reliable energy infrastructure and reduced need for new power plants

Federal Energy Management Program

Leading by example, saving energy and taxpayer dollars in federal facilities

FreedomCAR \& Vehicle Technologies Program

Less dependence on foreign oil, and eventual transition to an emissions-free, petroleum-free vehicle

Geothermal Technologies Program

Tapping the Earth's energy to meet our heat and power needs

Hydrogen, Fuel Cells \& Infrastructure Technologies Program

Paving the way toward a hydrogen economy and net-zero carbon energy future

Industrial Technologies Program

Boosting the productivity and competitiveness of U.S. industry through improvements in energy and environmental performance

Solar Energy Technology Program

Utilizing the sun's natural energy to generate electricity and provide water and space heating

Weatherization \& Intergovernmental Program

Accelerating the use of today's best energy-efficient and renewable technologies in homes, communities, and businesses

Wind \& Hydropower Technologies Program

Harnessing America's abundant natural resources for clean power generation

To learn more, visit www.eere.energy.gov 